\title{
The Kallikrein-Kinin System: Current and Future Pharmacological Targets
}

\author{
Marie Eve Moreau ${ }^{1}$, Nancy Garbacki ${ }^{2}$, Giuseppe Molinaro ${ }^{1}$, Nancy J. Brown ${ }^{3}$, François Marceau ${ }^{4}$, \\ and Albert Adam ${ }^{1, *}$ \\ ${ }^{1}$ Faculty of Pharmacy, University of Montreal, 2900 boul. Édouard-Montpetit, C.P. 6128, Succursale Centre-Ville, \\ Montréal (Québec), Canada H3C $3 J 7$ \\ ${ }^{2}$ Laboratory of Human Physiology, University of Liège, 3 Avenue de l'Hôpital, Sart Tilman, Belgium B-4000 \\ ${ }^{3}$ Division of Clinical Pharmacology, Department of Medicine, School of Medicine, Vanderbilt University, \\ 60 Robinson Research Building (RRB), Nashville, TN 37232-6602, USA \\ ${ }^{4}$ Centre de Recherche en Rhumatologie et Immunologie, CHUL-CHUQ, 2705 boul. Laurier, \\ Québec (Québec), Canada, G1V $4 G 2$
}

Received May 24, 2005

\begin{abstract}
The kallikrein-kinin system is an endogenous metabolic cascade, triggering of which results in the release of vasoactive kinins (bradykinin-related peptides). This complex system includes the precursors of kinins known as kininogens and mainly tissue and plasma kallikreins. The pharmacologically active kinins, which are often considered as either proinflammatory or cardioprotective, are implicated in many physiological and pathological processes. The interest of the various components of this multi-protein system is explained in part by the multiplicity of its pharmacological activities, mediated not only by kinins and their receptors, but also by their precursors and their activators and the metallopeptidases and the antiproteases that limit their activities. The regulation of this system by serpins and the wide distribution of the different constituents add to the complexity of this system, as well as its multiple relationships with other important metabolic pathways such as the renin-angiotensin, coagulation, or complement pathways. The purpose of this review is to summarize the main properties of this kallikrein-kinin system and to address the multiple pharmacological interventions that modulate the functions of this system, restraining its proinflammatory effects or potentiating its cardiovascular properties.
\end{abstract}

Keywords: kallikrein-kinin system, $\mathrm{B}_{1}$ and $\mathrm{B}_{2}$ receptors, metallopeptidase, pharmacological agent

\section{Introduction. \\ Part I: The Kallikrein-Kinin System...................... 8 \\ I- Kinins ................................................ 8 \\ 1. The kininogens: precursors of kinins ........ 8 \\ 1.1 High-molecular-weight kininogen \\ 1.2 Low-molecular-weight kininogen \\ 2. The kinin-forming systems \\ 2.1 The plasma kinin forming system \\ 2.1.1 Plasma prekallikrein \\ 2.1.2 Contact system activation of plasma \\ 2.2 Endothelial cells and kinin forming activity}

*Corresponding author. FAX: +1-514-343-2102

E-mail: albert.adam@umontreal.ca
2.3 Tissue kallikrein-kinin system

2.4 Other kinin forming enzymes

3. Regulation of the kininogenase activity ...... 10

II- Metabolism of Kinins .................................. 11

1. Angiotensin I-converting enzyme (ACE) .... 11 1.1 Definition

1.2 Synthesis, regulation, and localization

1.3 Properties

1.3.1 Angiotensinase vs kininase

1.3.2 ACE GPIase activity

1.3.3 ACE: a signal transduction molecule

1.3.4 ACE insertion/deletion polymorphism

Invited article 
2. Neprilysin

2.1 Definition

2.2 Synthesis, localization, and properties

3. Aminopeptidase $P$

3.1 Definition

3.2 Synthesis, regulation, and localization

3.3 Properties

4. Carboxypeptidase $N$ and $M$.

5. Other peptidases

III- Kinin Receptors

1. Pharmacological classification.

1.1 Potency order of agonists

1.2 Affinity of antagonists

2. Molecular classification.

2.1 Organization and structure of the receptor genes

2.2 Receptors expression and regulatory elements in gene promoters

2.3 Second messengers

2.4 Receptor desensitization

Part II: The Kallikrein-Kinin System:

Pathophysiology and Pharmacological

Target

I- The Kinin Forming System in Plasma ......... 19

1. Genetic defects..

1.1 Defects of the contact system components

1.2 Defect in the control of the contact system:

C1 inhibitor

1.2.1 Definition

1.2.2 Pathophysiology

12.3 Treatment of hereditary angioedema

1.2.3.1 Serine proteases inhibitors

1.2.3.2 DX88

1.2.3.3 Attenuated androgens: Danazol ${ }^{\circledR}$, Stanozolol ${ }^{\mathbb{1}}$

1.2.3.4 Antifibrinolytic drugs: tranexamic acid (Transamin ${ }^{\circledR}$, Cyklokapron ${ }^{\circledR}$, Exacyl $^{\circledR}$, Cyklo-f $\left.f^{\circledR}\right)$
1.2.3.5 B $_{2}$-receptor antagonists: HOE 140 (Icatibant ${ }^{\circledR}$ or JE049 ${ }^{\circledR}$ )

2. Acquired diseases

2.1 Sepsis

2.2 Anaphylactoid and severe hypotensive reactions

3. Antithrombolytic treatment and kinins 21

II- The Metabolism of Kinins............................ 21

1. ACE: pathophysiology ……………............ 21

2. ACE inhibitors (ACEi) ............................. 21

2.1 Multicenter clinical randomized trials

2.2 Role of bradykinin in the cardiovascular effects of ACEi

3. Vasopeptidase inhibitors (VPi) 22

3.1 Multicenter clinical randomized trials

3.2 Role of kinins in the cardiovascular effects of $V P i$

4. Kinins and side effects of metallopeptidase inhibitors.

III- Kinin Receptors....................................... 24

1. Receptor polymorphisms and pathology .... 24

1.1 Polymorphism of $B_{2}$ receptors

1.1.1 $+9 /-9$, exon 1 polymorphism

1.1.2 $\left(C^{-58} \rightarrow T\right)$, promoter region polymorphism

1.1.3 $\left(C^{181} \rightarrow T\right)$, exon 2 polymorphism

1.2 Polymorphisms of $B_{1}$ receptors: $\left(G^{-699} \rightarrow C\right)$ substitution

2. Kinin receptors as pharmacological

targets .

2.1 Cardiovascular and renal diseases

2.2 Inflammation

2.3 Pain and neurological applications

2.4 Diabetes

2.5 Renal disease

2.6 Airway disease

2.7 Angioedema

Conclusion 28

\section{Introduction}

The existence of the kallikrein-kinin system was first discovered almost one century ago when Abelous and Bardier, in 1909, showed the hypotensive effect of human urine (1). Since that time, this system has been and continues to be the subject of intensive research. In fact, more than 30,000 papers are referenced for kallikrein-kinin in Medline for the last 50 years.

Such a scientific interest is explained in part because of the duality and the complexity of this system. Bradykinin (BK) is at the center of this system; however, it is not the only pharmacologically active kinin. The kinins
(BK-related peptides) are generated from two types of kininogens, mainly by two types of activators: tissue and plasma kallikreins. In fact, two classes of kinin receptor ligands are now recognized corresponding to each receptor subtype ( $\mathrm{B}_{1}$ and $\mathrm{B}_{2}$ receptors). The expression of these receptors is regulated by specific mechanisms. The duality also exists as to the pharmacological activity of kinins, which are often considered as either proinflammatory or protective (namely for heart, kidney function, angiogenesis-promoting) depending on the experimental approach, or scientific interest. This system is also complex in its distribution, as the different constituents have been shown to be present in plasma, 
but also on blood cells, in various tissues or their exocrine secretions. The autocrine or paracrine activity of kinins is regulated by several metallopeptidases, the relative importance of which varies from one biological medium to the other. Finally, the regulation of this system by serpins adds to the complexity of the system, as well as its multiple relationships with other important metabolic pathways such as the renin-angiotensin, coagulation or complement pathways.

An understanding of the multifaceted aspects of the different constituents of this system is necessary to grasp the complexity of its multiple pharmacological activities, mediated not only by kinins and their receptors, but also by their precursors and their activators, and the metallopeptidases and the antiproteases that limit their activities.

The purpose of this review is, first, to summarize the main properties of the various constituents of this complex but fascinating system. We will secondly address the multiple pharmacological interventions that modulate the functions of the kallikrein-kinin system and their clinical applications.

\section{Part I: The Kallikrein-Kinin System}

The kallikrein-kinin system represents a metabolic cascade that, when activated, triggers the release of vasoactive kinins. This complex multi-protein system includes the serine proteases tissue and plasma kallikreins, which liberate kinins from high- and lowmolecular-weight kininogen (HK and LK). Kinins exert their pharmacological activities by binding specific receptors, before being metabolized by various peptidases.

\section{I- Kinins}

In humans and in most mammals, the term "kinin" refers to the nonapeptide, BK (Arg-Pro-Pro-Gly-PheSer-Pro-Phe-Arg), the decapeptide kallidin (KD: Lys$\mathrm{BK})$, and their carboxy-terminal des-Arg metabolites. Other kinins, like T-kinin (Ile-Ser-BK) and Met-T-kinin have only been reported in the rat (2).

Kinins are implicated in many physiological and pathological processes. By virtue of their ability to activate endothelial cells, leading to vasodilation, increased vascular permeability, tissue-type plasminogen activator (t-PA) release, production of nitric oxide (NO), and mobilization of arachidonic acid, they participate in physiological (regulation of blood pressure, renal and cardiac functions) and pathological processes like inflammation.

\section{The kininogens: precursors of kinins}

$\mathrm{HK}$ and LK, the precursors of kinins (BK and KD), are produced from a structural gene localized to chromosome $3 \mathrm{q} 26 \rightarrow$ qter that is thought to have originated as a result of two successive duplications of a primordial kininogen gene $(3,4)$. This gene consists of 11 exons. The first 9 exons encode the heavy chain. The 10th exon codes for BK and the light chain of HK; the light chain of $\mathrm{LK}$ is coded by exon 11 .

Both HK and LK have an identical aminoacid sequence starting at the $\mathrm{N}$-terminus (heavy chain) and continuing to 12 aminoacids beyond the BK moiety but differ at the C-terminal because of alternative splicing, thereby providing the two kininogens with different light-chain moieties $(3,4)$. In fact, both native proteins are produced as single chain polypeptides, and the light or heavy chain nomenclature refers to their disulfide bond-assembled structure after activation by kallikrein cleavage.

\subsection{High-molecular-weight kininogen (HK)}

$\mathrm{HK}$, an $\alpha$-globulin, circulates in plasma as an $88-$ to $120-\mathrm{kDa}$ single-chain glycoprotein at a concentration of 70 to $90 \mu \mathrm{g} / \mathrm{mL}$ (5). This kininogen is a multifunctional protein composed of six domains. Each domain is thought to have distinct functions. HK heavy chain (64 kDa) contains domains 1,2 , and 3 . The light chain (45 to $58 \mathrm{kDa}$ ) is comprised of domains 5 and 6 . The heavy chain and light chain are linked by domain 4 , which contains the BK sequence. Domain 1 has a low affinity calcium-binding site (6), domains 2 and 3 have specific sequences (Gln-Val-Val-Ala-Gly) that inhibit cysteine proteases (7), and domain 3 has platelet- and endothelial cell-binding activity (8). Domain 5 has cellbinding sites, antiangiogenic properties, and sequences for heparin binding $(9-11)$. HK binds to negatively charged surfaces through the histidine region of the light chain corresponding to domain 5. Domain 6 has prekallikrein and factor XI-binding sites (12). The ability to bind to a surface (domain 5) and simultaneously complex factor XI or prekallikrein (domain 6) is responsible for the cofactor activity of $\mathrm{HK}$ in contact activation of plasma (13).

\subsection{Low-molecular-weight kininogen (LK)}

LK is a $\beta$-globulin present in human plasma at a concentration between 170 and $220 \mu \mathrm{g} / \mathrm{mL}$ (5). It has a molecular mass ranging from 50 to $68 \mathrm{kDa}(5,14)$. LK has the same basic structure as HK: the same aminoterminal heavy chain of 50 to $60 \mathrm{kDa}$ linked to a carboxy-terminal light chain by the kinin segment (14). The light chain of LK is only 4 to $5 \mathrm{kDa}$ and lacks contact activation and prekallikrein-binding sites. The 
function(s) of the light C-terminal chain of LK remain unknown.

\section{The kinin-forming systems}

Classically, there are two main pathways by which kinins are generated (Fig. 1). The plasma kallikreinkinin system, by far the more complex, initiates activation of the intrinsic coagulation pathway. The second and simpler pathway of kinin generation involves tissue kallikrein and its substrate, LK. Each of these enzyme systems may play different pathophysiological functional roles.

\subsection{The plasma kinin forming system}

The plasma kinin forming system, also called the

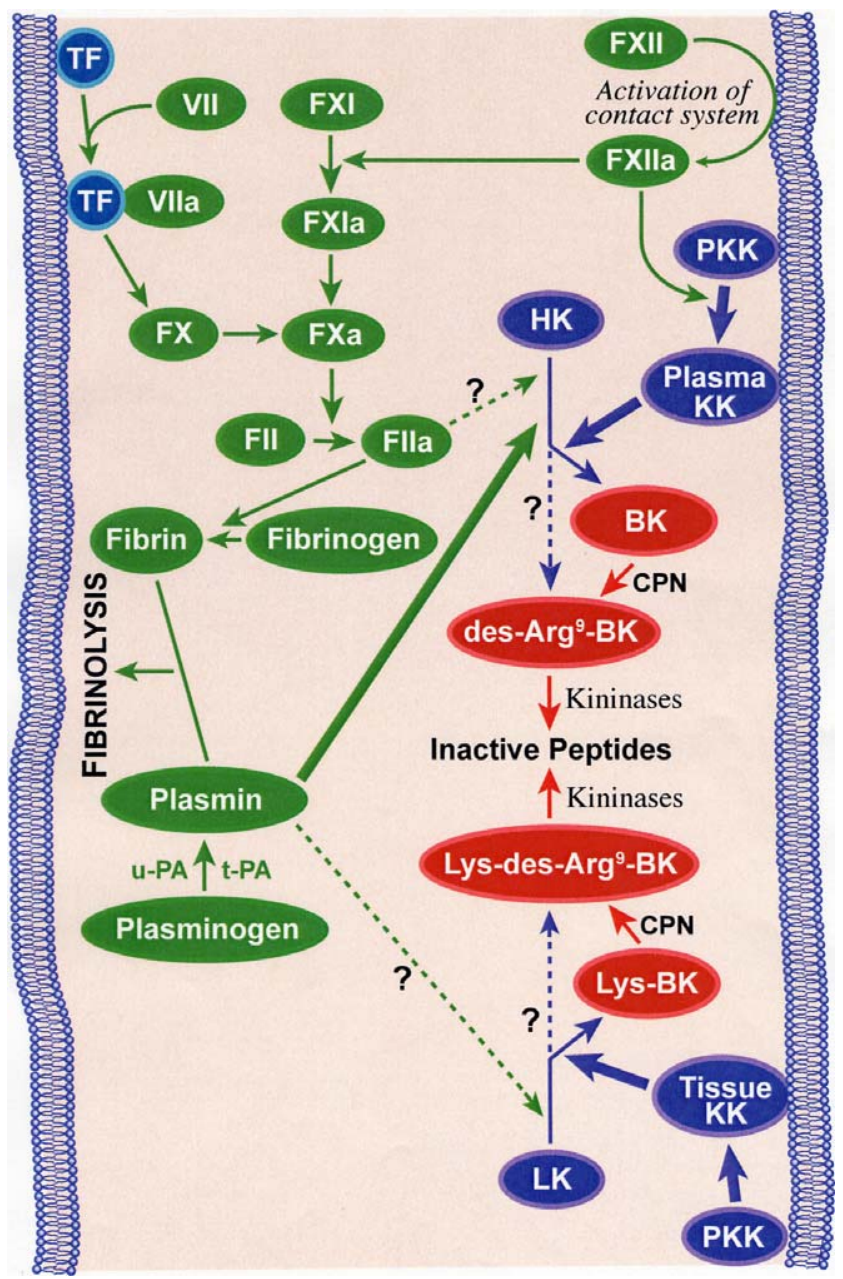

Fig. 1. The kinin-forming systems. The kallikrein-kinin system and its interactions with both intrinsic and extrinsic coagulation cascades and fibrinolysis. Solid lines are established pathways, whereas dashed lines are speculative or experimental activation pathways. TF: tissue factor; PKK: prekallikrein; HK: high-molecular-weight kininogen; LK: low-molecular-weight kininogen; BK: bradykinin; CPN: carboxypeptidase; t-PA: tissue plasminogen activator; u-PA: urokinase plasminogen activator. contact system of plasma, consists of 3 serine proenzymes (factor XII or Hageman factor, factor XI, and prekallikrein) and the kinin precursor HK.

\subsubsection{Plasma prekallikrein}

Chromosomal localization of the human plasma kallikrein gene was mapped to the $\mathrm{q} 34-\mathrm{q} 35$ region of the long arm of chromosome 4 (15). Plasma kallikrein (EC 3.4.21.34), a serine protease, is encoded by a single gene, $K L K B 1$, and synthesised in the liver. It is predominantly secreted by hepatocytes as an inactive molecule called prekallikrein that circulates in plasma as a heterodimer complex bound to HK with 1:1 molar stoichiometry $(16,17)$. Prekallikrein is a single chain $\alpha$-globulin that is present in the plasma of humans and of other animal species at a concentration of 35$50 \mu \mathrm{g} / \mathrm{mL}$. About $80-90 \%$ of prekallikrein is normally complexed to HK $(16,18)$.

\subsubsection{Contact system activation of plasma}

Contact of plasma with a negatively charged surface leads to the binding and autoactivation of factor XII (Hageman factor) to factor XIIa, activation of prekallikrein to kallikrein by factor XIIa, and cleavage of HK by kallikrein to release BK (19). Factor XII activation is not only a first step in the initiation of the intrinsic clotting cascade and the generation of kinins, but it also leads to the activation of the complement pathway (20).

In vitro, non-physiologic substances, such as glass (negatively charged silicates), carrageenan, kaolin, and a sulfated polysaccharide dextran sulfate (21) activate the contact system of plasma. In vivo, the physiologic surface remains unknown. Pathologic initiators may include proteoglycans (sulfate residues on heparin sulfate or chondroitin sulfate or mast-cell heparin). Endotoxins (lipopolysaccharide (LPS)) and crystals of uric acid or pyrophosphate (22) have also been hypothesized to be pathological activators. This intrinsic coagulation/kinin-forming cascade appears to be in equilibrium in plasma even in the absence of any exogenous surface. That is, activation occurs continuously at a finite rate, but is held in check by plasma inhibitors (19).

Plasma kallikrein cleaves human HK in a two-step process. First, HK is cleaved at the $\mathrm{Arg}^{389}-\mathrm{Ser}^{390}$ bond of the carboxy-terminal portion of the $\mathrm{BK}$ sequence, leaving the BK attached to the carboxy-terminal end of the heavy chain, and the sequence Leu ${ }^{378}$-Met-Lys$\mathrm{Arg}^{381}$ is cleaved at the $\mathrm{Lys}^{380}-\mathrm{Arg}^{381}$ bond to liberate BK from the heavy chain (23). As a result of domain rearrangement, $\mathrm{HKa}$ acquires new properties. Recent observations suggest that HKa inhibits endothelial cell 
proliferation and neovascularisation due to antiapoptotic properties. This property contrasts with the angiogenic effect of HK and LK, due to the release of BK (24).

\subsection{Endothelial cells and kinin forming activity}

Another mechanism for initiation of the activation of the kallikrein-kinin system depends on binding of components of the contact activation cascade on the surface of cells as leukocytes, platelets, endothelial cells, and myocytes (25).

HK specifically binds to platelets, granulocytes, and endothelial cells in a zinc-dependent, saturable and reversible reaction $(26,27)$. The dissociation constant equals $15 \mathrm{nM}$, indicating high affinity binding (21). This binding involves both the heavy (domain 3 ) and light (domain 5) chains of HK (28), which could be considered as a receptor for prekallikrein on endothelial cells $(29-31)$. Binding of $\mathrm{HK}$ to endothelial cells leads to activation of prekallikrein to kallikrein $(11,25,31)$ and presumably a release of BK from $\operatorname{HK}(31,32)$.

The interaction of HK with endothelial cell membranes involves a multiprotein receptor complex comprising at least cytokeratin $1, \mathrm{gC} 1 \mathrm{qR}$, and the urokinase plasminogen activator receptor (u-PAR) $(33-38)$. These three proteins co-localize on the endothelial cell membrane (39). The same three proteins form a receptor complex for factor XII, but binding of factor XII in vivo is likely limited both by the low plasma concentration of free $\mathrm{Zn}^{2+}$, which is below the requirement for factor XII binding, and by the much higher plasma concentration of HK (40).

\subsection{Tissue kallikrein-kinin system}

Tissue (glandular) kallikrein (EC 3.4.21.35) is an acid glycoprotein which differs from plasma kallikrein. This tissue serine protease is encoded by one of the kallikrein gene family, KLK1 gene, located on chromosome 19 locus q13.2-q13.4 (41, 42). Tissue kallikrein is widely distributed (kidney, blood vessels, central nervous system (CNS), pancreas, gut, salivary and sweat glands, spleen, adrenal, and neutrophils) (17, 42 ), and this wide distribution suggests a paracrine function (43). The origin of tissue kallikrein detected in plasma has been suggested to be the exocrine glands. Tissue kallikrein is synthesized as a proenzyme, prokallikrein, which is inefficiently activated by plasmin or plasma kallikrein (44).

Tissue kallikrein releases KD from LK (42), cleaving the $\mathrm{Met}^{379}$-Lys $^{380}$ and $\mathrm{Arg}^{389}-\mathrm{Ser}^{390}$ bonds (45). Although LK is considered to be the main substrate of tissue kallikrein, tissue kallikrein is also capable of cleaving HK.

\subsection{Other kinin forming enzymes}

In addition to tissue and plasma kallikrein, other serum and tissue proteases have a kinin forming capacity (46). Plasmin, which is responsible for lysis of the fibrin clot, releases not only BK but also des-Arg ${ }^{9}$-BK from HK (47), circulates in plasma as an inactive zymogen, plasminogen. The presence of plasminogen activators and their inhibitors is essential in controlling fibrinolysis (48).

The major activator of plasminogen in vivo is tissue plasminogen activator (t-PA), a serine protease synthesized and secreted by endothelial cells as a single chain active enzyme (46). In the absence of fibrin, t-PA is an inefficient activator of plasminogen but the binding of t-PA to fibrin greatly accelerates the activation of plasminogen. Urokinase or urinary type plasminogen activator (u-PA) can also activate plasminogen and plays an important role in the degradation of the extracellular matrix. This facilitates the migration of cells which is important in wound healing and in tumour invasion and metastasis. u-PA can be of primary importance for cell-mediated activation of plasminogen in tissues, whereas t-PA, possessing a high affinity for fibrin, can be of primary importance for the lysis of fibrin clots in the circulation (49).

Factor XIIa, XIa, and kallikrein are also capable of converting plasminogen to plasmin in vitro. The contribution of these enzymes to the activation of plasminogen in vivo is uncertain; in fact, deficiencies in these proteins do not appear to lead to pathological states that could be explained by an impaired fibrinolysis (48).

\section{Regulation of the kininogenase activity}

Protease inhibitors regulate the contact activation of plasma. The serpins of plasma are namely $\mathrm{C} 1$-inhibitor $(\mathrm{C} 1 \mathrm{INH})$, antithrombin III, $\alpha_{2}$-macroglobulin, $\alpha_{1}$-protease inhibitor, and $\alpha_{2}$-antiplasmin $(19,50)$. However, $\mathrm{C} 1 \mathrm{INH}$ is the major regulator of the intrinsic system, interfering with the activities of factor XIIa and of kallikrein (51). Both $\mathrm{C} 1 \mathrm{INH}$ and $\alpha_{2}$-macroglobulin account for more than $90 \%$ of the kallikrein inhibitory activity of plasma.

The regulatory mechanism of tissue kallikrein remains partly unknown. Kallistatin and aprotinin are an example of serine protease inhibitors. Unlike many other serpins that are present only in plasma, kallistatin can be detected in various tissues, cells, and fluids, where it regulates the activity of tissue kallikrein $(52,53)$.

Plasmin, t-PA, and u-PA are also regulated by inhibitors in the serpin family. The primary inhibitor of active plasmin is $\alpha_{2}$-antiplasmin. Similarly, antithrombin, $\alpha_{1}$-antitrypsin, and C1INH have been shown to inhibit plasmin in vitro but have a minimal physio- 
logical effect in blood. Inhibitors of t-PA play an important role in regulating fibrinolysis. Currently, four distinct types of plasminogen activator inhibitors (PAI) have been described: PAI-1, PAI-2, PAI-3, and protease nexin. Of these, PAI-1 is the most important in inhibiting t-PA in plasma. PAI-1 is present in molar excess over t-PA; hence the majority of t-PA circulates bound to PAI-1, thereby preventing its interaction with plasminogen and thus a premature lysis of fibrin and a systemic fibrinolysis (54).

\section{II- Metabolism of Kinins}

The nature and properties of the various peptidases capable of metabolizing kinins have been extensively reviewed (55). We have experimental evidences that 4 metallopeptidases are mainly responsible for the metabolism of BK. These are angiotensin I-converting enzyme (ACE), aminopeptidase P (APP), neutral endopeptidase 24.11 (NEP, neprilysin), and carboxypeptidases $\mathrm{M}$ and $\mathrm{N}$ (CPM, CPN). The importance of these peptidases depends on the animal species, the analytical approach, the biological milieu, and the pathophysiological context. Interestingly, these peptidases are zinc metallopeptidases, that is, they all require zinc in their catalytic site to hydrolyse substrates, and are membrane-bound glycoproteins, except CPN, which is a soluble tetrameric glycoprotein. However, they are all present in a soluble form in biologic fluids.

\section{Angiotensin I-Converting Enzyme (ACE) 1.1 Definition}

ACE (EC 3.4.15.1) is a well-characterized type I ectoenzyme membrane anchored $\mathrm{Zn}^{2+}$-dependent dipeptidyl carboxypeptidase that regulates bioactivities of vasoactive peptides such as angiotensin I (Ang I) and $\mathrm{BK}$, responsible for the control of blood pressure (56).

Two distinct forms of ACE are expressed in humans, a larger one $(150-180 \mathrm{kDa})$ usually referred to as somatic ACE that is composed of approximately 1300 aminoacids and is present in most tissues (vascular endothelial surface of the lungs and on brush-border membranes of kidney, intestine, placenta, and choroid plexus) and a smaller isoenzyme referred to as the germinal form, testicular ACE $(100-110 \mathrm{kDa})$, with only 730 aminoacids and is found exclusively in the testicles and appears to be involved in male fertility $(56,57)$.

The somatic form has two homologous metalloproteinase domains ( $\mathrm{N}$ - and $\mathrm{C}$-terminal domains) with an overall $60 \%$ homology in both nucleotide and aminoacid sequence, each containing a canonical $\mathrm{Zn}^{2+}-$ binding sequence motif: HEXXH (His-Glu-X-X-His) and bearing a functional active site $(58,59)$. The stoichiometry value of 1:1 for the complete inhibition of the enzyme indicates that both active sites would work in a cooperative manner (60).

The testicular ACE has a single domain corresponding to the C-terminal domain of somatic ACE (61) together with the hydrophobic membrane-anchoring domain and a small $\mathrm{N}$-terminal region that has multiple $O$-linked oligosaccharides (62).

Although ACE is primarily a membrane-bound protein, a soluble form does exist in many body fluids and is the result of post-translational proteolytic cleavage in the juxtamembrane stalk by a membrane protein secretase or sheddase, itself a zinc metallopeptidase $(63,64)$. Although the ACE secretase has not yet been identified, studies with a range of hydroxamic acid-based inhibitors have shown that it has a remarkably similar inhibition profile to the amyloid precursor protein $\alpha$-secretase, leading to the conclusion that the two secretases are, at the very least, closely related (65). Human plasma ACE originates from endothelial cells, while in other body fluids ACE originates from epithelial, endothelial, or germinal cells (66).

A number of proteins with sequences related to ACE have been described, but the only mammalian relative to be found is ACE2. Similar to ACE, ACE2 is also a type I integral membrane glycoprotein found on the surface of endothelial and epithelial cells, although it has a more limited tissue (testis, heart, kidney) distribution than ACE. ACE2 consists of a single active site domain that, by sequence comparison, more closely resembles the N-domain than the $\mathrm{C}$-domain of somatic ACE. However, ACE2 differs from ACE in that it acts as a carboxypeptidase removing single aminoacid residues from its substrates, which include angiotensin II (Ang II) with high catalytic efficiency $\left(k_{\text {cat }} / K_{\mathrm{m}}=1.9 \times 10^{6} \mathrm{M}^{-1}\right.$. $\mathrm{s}^{-1}$ ) (67). ACE2 efficiently hydrolyzes des-Arg'-BK $\left(k_{\text {cat }} / K_{\mathrm{m}}=1.3 \times 10^{5} \mathrm{M}^{-1} \cdot \mathrm{s}^{-1}\right)$, but fails to hydrolyze BK itself (68). Also, ACE2 is not inhibited by some inhibitors of ACE. Since the discovery of ACE2, some authors have begun to refer to ACE as ACE1 $(69,70)$.

\subsection{Synthesis, regulation, and localization}

Somatic and germinal ACE are transcribed from the same gene (17q23) using alternative promoters (71). Cloning of the gene that encodes ACE revealed the relationship between the two isoforms. Besides their different tissue specificity, expression of the two ACE transcripts is regulated by different developmental and hormonal controls; for example, the endothelial enzyme is induced by glucocorticoids, whereas the testicular form is stimulated by androgens (71). 


\subsection{Properties}

\subsubsection{Angiotensinase vs kininase}

ACE catalyzes the conversion of the inactive decapeptide Ang I to the potent vasopressor octapeptide Ang II by the removal of the C-terminal dipeptide His'Leu $^{10}$.

Ang I is originally considered the main physiological substrate for ACE $\left(K_{\mathrm{m}}\right.$, approximately $\left.16 \mu \mathrm{M}\right)$. Because of its higher affinity $\left(K_{\mathrm{m}}\right.$, approximately $\left.0.18 \mu \mathrm{M}\right)$ for BK, ACE could also be now considered as a kininase (kininase II) $(72,73)$. As a peptidyl dipeptidase, ACE inactives BK by hydrolyzing two separate bonds on its $\mathrm{C}$-terminal end. It removes sequentially the dipeptide $\mathrm{Phe}^{8}-\mathrm{Arg}^{9}$ and next cleaves the $\mathrm{Phe}^{5}-\mathrm{Ser}^{6}$ bond to generate the second dipeptide $\mathrm{Ser}^{6}-\mathrm{Pro}^{7}$, transforming $\mathrm{BK}$ into its inactive final $\mathrm{BK}_{[1-5]}$ product $(74,75)$. ACE also metabolizes des-Arg ${ }^{9}$-BK by removing the carboxyterminal tripeptide $\mathrm{Ser}^{6}-\mathrm{Pro}^{7}-\mathrm{Phe}^{8}$, yielding the same final pentapeptide.

\subsubsection{ACE GPIase activity}

Recently, Kondoh et al. reported that ACE has a GPIase activity which allows the release of a membrane glycosylphosphatidylinositol (GPI)-anchored protein. They have found that ACE-specific inhibitors, such as captopril and lisinopril, which bind to the catalytic center and completely inhibit the peptidase activity, had only a minor inhibitory effect on this GPIase activity which does not require the zinc ion (76). This new activity of ACE which is different from the GPIase activity of GPI-specific phospholipase D (GPI-PLD) $(76,77)$ and of phosphatidylinositol-specific phospholipase C (PI-PLC)-like could be of physiological importance in fertilization.

\subsubsection{ACE: a signal transduction molecule}

By its short cytoplasmic domain (29 aminoacids), ACE could also play a role as a signal transduction molecule. In fact, the cytoplasmic tail of ACE is phosphorylated in endothelial cells (78). ACE inhibitors as well as BK elicit outside-in signalling in these cells. They enhance the activity of ACE-associated protein kinase CK2, increasing its phosphorylation of ACE, and lead to the activation of c-Jun N-terminal kinase (JNK) as well as the accumulation of phosphorylated c-Jun in the nucleus (79).

\subsubsection{ACE insertion/deletion polymorphism}

Population studies indicated that the large interindividual variability in plasma ACE levels is genetically determined. Regulation, as well as tissue ACE activity are under strong genetic control. An insertion /deletion (I/D) polymorphism located in the noncoding region of the gene is associated with differences in the level of ACE in plasma and cells. The insertion that gives rise to the I allele is an alu repeat sequence (287 bp) in intron 16 of the ACE gene; the D allele results from the absence of the above insertion. There is a relationship between the ACE I/D polymorphism and circulating ACE activity, such that ACE activity is highest in individuals homozygous for the D allele, lowest in those homozygous for the I allele and intermediate in heterozygotes.

Mean serum ACE level in DD homozygotes are nearly twice the value measured in II plasma, while DI heterozygous have intermediate activities $(80-82)$. Although some association between the I/D polymorphism with the incidence of cardiovascular and Alzheimer diseases, the results remain inconsistent $(83-87)$. However, ACE genotype determines BK degradation and suggests another mechanism whereby the ACE D allele could be associated with deleterious cardiovascular effects (82).

\section{Neprilysin (NEP) \\ 2.1 Definition}

NEP (EC 3.4.24.11, neprilysin) is a type II surface protein with a short membrane-proximal stalk region that is not sensitive to proteolytic activity of any particular secretase (88). It is the prototype zinc peptidase of the M13 membrane metalloendopeptidase (MME) family. This family includes other peptidases of potential pathophysiological interest: ECE-1 and ECE-2, which generate the vasoconstrictor endothelins from big endothelin; the erythrocyte cell-surface antigen KELL; PHEX, associated with congenital X-linked hypophosphatemic ricket; ECEL1, present in CNS; SEP (MML1 or NL1) present in testis; and MMEL2 (89-91).

\subsection{Synthesis, localization, and properties}

Human NEP gene $(M M E)$ is localized to $3 \mathrm{q} 21-\mathrm{q} 27$ (92). First identified in the brush border of the kidney epithelial cells, where it represents $4-5 \%$ of the protein content, its immunoreactivity or activity has also been detected in cells or tissues as different as the CNS, the endothelium, testis, lungs, salivary glands, and bone marrow (93). NEP preferentially cleaves bonds on the amino-side of hydrophobic aminoacids residues. However, the physiological role of NEP depends on its tissue localization and the presence of the substrate.

Like ACE, NEP inactivates BK by sequentially removing dipeptide $\mathrm{Phe}^{8}-\mathrm{Arg}^{9}$ and tripeptide $\mathrm{Phe}^{5}-\mathrm{Ser}^{6}-$ $\mathrm{Pro}^{7}$ to yield $\mathrm{BK}_{[1-4]}$, an inactive metabolite. However, a prolonged incubation also results in the hydrolysis of the Gly ${ }^{4}-P^{5}{ }^{5}$ bond (94). In contrast to ACE, it is likely that NEP cleaves the Gly ${ }^{4}-\mathrm{Phe}^{5}$ bond of des-Arg ${ }^{9}-\mathrm{BK}$ 
to generate the same $\mathrm{BK}_{[1-4]}$-inactive peptides. NEP is the main enzyme responsible for the metabolism of kinins in the kidney and plays an important role in the metabolism of BK at the endothelium. In plasma, unlike ACE, NEP does not play a significant role in the metabolism of kinins (95).

Besides kinins, NEP also inactivates other peptides like enkephalins, neurokinins, and amyloid- $\beta$ peptide, a marker for Alzheimer disease of the CNS (96). In the kidney, it regulates the degradation of natriuretic peptides (97).

\section{Aminopeptidase P (APP) 3.1 Definition}

Human APP (X-prolyl aminopeptidase, EC 3.4.11.9) exists at least in two forms: a soluble cytosolic (cAPP) and membrane-bound (mAPP) APP forms. Both forms have an X-prolyl aminopeptidase activity (98). cAPP and mAPP share $43 \%$ of homology. cAPP is a homodimer of $70 \mathrm{kDa}$ subunits and the mature form APP has a predicted subunit molecular weight of $71 \mathrm{kDa}(99$, 100). mAPP is a heavily N-glycosylated, $\mathrm{Zn}^{2+}$-containing, peptidase and contains a C-terminally attached GPI membrane anchor that increases the overall subunit molecular weight to approximately $90 \mathrm{kDa}$. A secreted form of mAPP has recently been produced and characterized in vitro in a transfected HEK-293 cell line. This protein exhibits a molecular mass of $85 \mathrm{kDa}(101)$.

The effects of divalent metal ions on the activity of mammalian APPs appear to differ between the cytosolic and membrane-bound form of the enzyme (102). Indeed, whereas mAPP uses $\mathrm{Zn}^{2+}$ at the active site, human cAPP contains $\mathrm{Mn}^{2+}$ and is activated in vitro by the presence of $\mathrm{Mn}^{2+}$, but not $\mathrm{Zn}^{2+}$, which is inhibitory $(99,103)$.

There is evidence for the existence of another form of APP in mammals. The third isoform is hypothetical and has been identified on the basis of sequence homology. The chromosomal location of this isoform is 22q13.31q13.33. This isoform is predicted to have a subunit molecular weight of $57 \mathrm{kDa}$ and is therefore smaller than cAPP and mAPP (104).

\subsection{Synthesis, regulation, and localization}

The chromosomal location of the human cAPP gene $(X P N P E P L)$ is 10q25.3 (105) and the XPNPEP2 gene of mAPP localizes to chromosome Xq25-26.1 (106).

mAPP is located on the external side of the plasma membrane of vascular endothelial cells and on brush border membranes of epithelial cells in the intestine and the renal proximal tubule $(107-112)$.

\subsection{Properties}

cAPP exhibits broad substrate specificity and can cleave X-Pro dipeptides as well as longer peptides of the form X-Pro-Y-, where $\mathrm{X}$ and $\mathrm{Y}$ are of the common aminoacids $(113-115)$. Compared to cAPP, mAPP has much more restricted substrate specificity; it fails to hydrolyze X-Pro dipeptides and cleaves X-Pro-Ypeptides poorly when $\mathrm{X}$ is Pro or Gly or when $\mathrm{Y}$ is an aminoacid with a bulky side chain $(116-118)$.

Kinins are the best substrates for mAPP. In fact, the secreted form of mAPP exhibits a $K_{\mathrm{m}}$ of $75 \pm 15 \mu \mathrm{M}$ for BK and a $K_{\mathrm{m}}$ of $56 \pm 13 \mu \mathrm{M}$ for des-Arg'-BK. In human plasma, APP transforms BK and des-Arg'-BK into the inactive peptide $\mathrm{BK}_{[2-9]}$ and $\mathrm{BK}_{[2-8]}$, respectively, and is the major inactivating pathway for des- $\mathrm{Arg}^{9}-\mathrm{BK}$ in plasma $(55,95,119)$.

\section{Carboxypeptidase $N$ and $M(C P N, C P M)$}

Currently known as kininase I, both CPN and CPM are zinc metallopeptidases that exhibit a $41 \%$ sequence identity (120).

CPN (kininase I, EC 3.4.17.3) is a tetrameric protein synthetized in the liver and secreted in blood, although CPM (membrane-bound kininase I) is a GPI peptidase anchored at the membrane of lung and kidney epithelial cells. They cleave a variety of peptides containing a carboxy-terminal Arg or Lys. CPN inactivates complement anaphylatoxins $(\mathrm{C} 3 \mathrm{a}, \mathrm{C} 4 \mathrm{a}$, and $\mathrm{C} 5 \mathrm{a})$ by cleaving their carboxy-terminal Arg residue (121). Although likely, definitive evidence for such a metabolic role does not exist for CPM. Both carboxypeptidases transform $\mathrm{BK}$ and $\mathrm{KD}$ into des-Arg ${ }^{9}-\mathrm{BK}$ and des- $\mathrm{Arg}^{10}-\mathrm{KD}$, which are active metabolites via $B_{1}$ receptor (B1R). This kininase I activity constitutes a minor metabolic pathway unless ACE is inhibited $(55,121)$.

\section{Other peptidases}

The properties of dipeptidyl peptidase IV (DPP IV) have been extensively reviewed (122). DPP IV (CD26; EC 3.4.14.5) is a $110 \mathrm{kDa}$ plasma membrane glycoprotein ectopeptidase $(119,122)$. The most important physiological actions of DPP IV is on regulatory peptides in mammals. DPP IV degrades the inactive metabolite $\mathrm{BK}_{[2-9]}$ generated by APP and leads to the final $\mathrm{BK}_{[4-9]}$ product (122). Substance $\mathrm{P}$ is another example of a regulatory peptide for which DPP IV plays an additional role in the inactivation (123).

Aminopeptidase N (APN, CD13) is an ectoenzyme (EC 3.4.11.2) of the superfamily of zinc metalloproteases widely used as a marker of myelomonocytic cells in the diagnosis of hematopoietic, malignant disorders $(88,124)$. Because of its ectopeptidase activity, APN has also been implicated in the regulation of vasoactive peptides, neuropeptide hormones, and immunomodulating peptides such as interleukin- 6 and -8 (IL-6 
and IL-8, respectively) $(125,126)$. Its importance in the field of kinins is related to its ability to hydrolyze the Nterminal Lys residue in $\mathrm{KD}$ and des-Arg ${ }^{10}-\mathrm{KD}$; this reaction is functionally significant for the latter peptide which is the optimal agonist of the B1R in humans and other species. Indeed, the reaction product des- $\mathrm{Arg}^{9}$-BK has a much lower affinity at the human, rabbit, porcine, and bovine B1R. APN mediates the major inactivation pathway for des-Arg ${ }^{10}$-KD in the human isolated umbilical artery (127) and rabbit aorta (F. Marceau and A. Adam, unpublished observations). APN blockade with amastatin potentiates the hypotensive effect of the $\mathrm{B} 1 \mathrm{R}$ agonist des- $\mathrm{Arg}^{10}-\mathrm{KD}$ in the LPS-pretreated rabbit (128).

\section{III- Kinin Receptors}

Two types of G-protein-coupled receptors (GPCRs) mediate the cellular effects of kinins, the $\mathrm{B} 1 \mathrm{R}$ and $\mathrm{B}_{2}$ receptor $(\mathrm{B} 2 \mathrm{R})(129,130)$. The various pharmacological effects of the BK-related peptides, such as vasodilatation, increased vascular permeability, stimulation of sensorial and sympathetic nervous connections, and smooth muscle contraction, derive from the presence of these receptors on various cell types such as the vascular endothelium, primary sensory afferent neurons, vascular and nonvascular smooth muscle, epithelial cells, and perhaps some types of leukocytes. The two types of receptors were initially defined using pharmacological criteria, before their molecular characterization.

\section{Pharmacological classification}

The potency order of agonists and the affinity of antagonists and their properties are summarized in Table 1 for B1R and Table 2 for B2R.

\subsection{Potency order of agonists}

The B2R has a high affinity for "native" kinins (generated by either plasma or tissue kallikreins), BK, and $\mathrm{KD}$ in all mammalian species. None of the fragments of BK retain a significant affinity for the B2R. KD has also a significant activity for the human and rabbit $\mathrm{B} 1 \mathrm{R}$ (e.g., in radioligand binding assays), but in complex bioassay systems, BK or KD effects at B1R are often mediated by their des-Arg metabolites generated in situ (131). Indeed, the B1R is specialized across species to respond to kinin metabolites generated by arginine carboxypeptidases (either des-Arg'-BK, Lys-des-Arg ${ }^{9}$-BK or des-Arg ${ }^{10}$-KD) $(129,130)$. DesArg-BK is a highly selective agonist of the mammalian B1R, but of high affinity (nanomolar) only in rodents (the rat and mouse); the only natural kinin sequence with a subnanomolar affinity for the human, rabbit, porcine, and bovine B1R is Lys-des-Arg'-BK, suggesting that the B1R works in concert with the tissue kallikrein that generates its parent native peptide, KD (130).

\subsection{Affinity of antagonists}

Antagonists for the B1R were discovered almost 10 years before the antagonists for the B2R; thus, the receptor nomenclature is justified by the fact that it was the first to be pharmacologically fully defined. The first series of compounds capable of antagonizing BK and des-Arg ${ }^{9}$-BK with specificity for B1R included the prototype $\left[\mathrm{Leu}^{8}\right]$ des-Arg- $\mathrm{BK}$ (132). However, this prototype exhibits fairly high partial agonist behavior in some species, especially in the rat and mouse (130). This has practical implications because one of the emerging therapeutic applications of B1R antagonists, analgesia, is commonly evaluated using models involving these species.

The first generation of $\mathrm{B} 2 \mathrm{R}$ antagonists was based on [D-Phe] - BK (133), but these early peptidic compounds showed an antagonist/partial agonist activity and a low potency. This problem was progressively solved with the second generation of $\mathrm{B} 2 \mathrm{R}$ antagonists in which rigidity was added to the peptide backbone by introducing non-natural aminoacid residues; thus, the spatial orientation of the C-terminal region of the peptide molecule critical for antagonism was more precise. Optimal peptide B2R antagonists retain both $\mathrm{Arg}^{1}$ and $\mathrm{Arg}^{9}$ residues and B1R agonists or antagonists typically lack $\mathrm{Arg}^{9}$ (as in $\left[\mathrm{Leu}^{8}\right]$ des-Arg ${ }^{9}-\mathrm{BK}$ ), just like agonists; furthermore, the N-terminal Lys residue present in KD also confers high affinity to peptide B1R antagonists in human, rabbit, and other species (as in Lys-[Leu $\left.{ }^{8}\right]$ desArg'-BK).

HOE 140 (D-Arg-[Hyp $\left.{ }^{3}, \mathrm{Thi}^{5}, \mathrm{D}-\mathrm{Tic}^{7}, \mathrm{Oic}^{8}\right]$-BK, Icatibant) is a representative of the second generation of peptide B2R antagonists (134) and has been exploited in more than 700 research papers and several clinical studies. Significant species-related differences in potency and competitive behavior are typically seen with kinin receptor antagonists; thus HOE 140 is potent and competitive at the human B2R, but insurmontable and atypically induces a slow B2R endocytosis of the rabbit $B 2 R$ (135). The selectivity of HOE 140 for the human $\mathrm{B} 2 \mathrm{R}$ is fair, but not complete; the fragment des- $\mathrm{Arg}^{10}$ HOE 140 is predominantly a B1R antagonist (130). Second generation B1R antagonists include the Nterminal Lys residue or its analog Orn that affords high affinity for the human B1R (as in B-9858= LysLys-[Hyp $\left.{ }^{3}, \mathrm{Igl}^{5}, \mathrm{D}-\mathrm{Igl}^{7}, \mathrm{Oic}^{8}\right]$ des-Arg $-\mathrm{BK}$ or R-954 = AcOrn-[Oic ${ }^{2}, \alpha-\mathrm{MePhe}^{5}$, D- $\left.\beta \mathrm{Nal}^{7}, \mathrm{Ile}^{8}\right]$ des-Arg ${ }^{9}$-BK) (136). The presence of D-Arg instead of Lys, as in des-Arg ${ }^{10}$ - 
Table 1. Pharmacological and clinical application of kinin $B_{1}$-receptor ligands

\begin{tabular}{|c|c|c|c|}
\hline Ligands & Application & Studies & References \\
\hline \multicolumn{4}{|l|}{$\underline{\text { Agonists }}$} \\
\hline \multirow[t]{2}{*}{ R-838 (Sar-[D-Phe ${ }^{8}$ ]des-Arg $\left.{ }^{9}-B K\right)$} & Metabolically stable & Rabbit & 128 \\
\hline & $\begin{array}{l}\text { High affinity and selectivity } \\
\text { Hypertension } \\
\text { Stimulation of vasculature formation } \\
\text { (following ischemia) }\end{array}$ & Rodent & 130,281 \\
\hline \multicolumn{4}{|l|}{ Antagonists } \\
\hline \multirow[t]{3}{*}[\mathrm{Leu}^{8}]{$\mathrm{des}-\mathrm{Arg}^{9}-\mathrm{BK}$} & Pain & Rat & 132 \\
\hline & & Mice & 302,317 \\
\hline & Ischemic vascular disease & Mice & 130,281 \\
\hline Lys-[Leu $\left.{ }^{8}\right]$ des-Arg'-BK & Optimal B1R antagonist & Human B1R & 130 \\
\hline Ac-Lys-[MeAla ${ }^{6}$ Leu $\left.^{8}\right]$ des-Arg 9 -BK & $\begin{array}{l}\text { Metabolically stable (not very potent } \\
\text { compared with the affinity of the } \\
\left.\text { reference compound Lys-[Leu }{ }^{8}\right] \text { des-Arg'-BK) }\end{array}$ & Rabbit & 318 \\
\hline \multirow[t]{2}{*}{ R-715 (Ac-Lys- $\left[\beta \mathrm{D}-\mathrm{Nal}^{7}, \mathrm{Ile}^{8}\right]$ des-Arg $\left.{ }^{9}-\mathrm{BK}\right)$} & High affinity & Human and rabbit B1R & 130 \\
\hline & Allergic lung inflammation & Mice & 319 \\
\hline \multirow{2}{*}{$\begin{array}{l}\text { B9858 (Lys-Lys-[Hyp }{ }^{3}, \text { Igl }^{5}, \text { D-Igl } \\
\text { Oic }\end{array}$} & Fairly high selectivity for B1R due to Lys ${ }^{0}$ & Human and rabbit B1R & 320 \\
\hline & Metabolically stable residue & & \\
\hline \multirow[t]{2}{*}{ des-Arg ${ }^{10}$-HOE 140} & Residual antagonistic effects on $\mathrm{B} 2 \mathrm{R}$ & $\begin{array}{l}\text { Rabbit jugular vein, guinea pig ileum, } \\
\text { rabbit aorta }\end{array}$ & 321 \\
\hline & Moderate affinity & & \\
\hline B9430 (D-Arg-[Hyp ${ }^{3}, \mathrm{Igl}^{5}$, D-Igl $\left.\left.{ }^{7}, \mathrm{Oic}^{8}\right]-\mathrm{BK}\right)$ & $\begin{array}{l}\text { Mixed B1R and B2R antagonist even if } \\
\text { desArg } \text { fragment has substantial }_{\text {selectivity for B1R }}\end{array}$ & $\begin{array}{l}\text { Demonstration of compatibility of B1R } \\
\text { and B2R structure by the accommodation } \\
\text { of a single antagonist pharmacophore }\end{array}$ & 322 \\
\hline \multirow{2}{*}{$\begin{array}{l}\text { R-954 (Ac-Orn-[Oic }{ }^{2}, \alpha-\mathrm{MePhe}^{5}, \mathrm{D}-\beta \mathrm{Nal}^{7} \\
\mathrm{Ile}^{8} \text { ]des-Arg'-BK) }\end{array}$} & Allergic lung inflammation & Mice & 319,323 \\
\hline & Airway allergy & Rat model, speculative on human & 324 \\
\hline PS020990 & $\begin{array}{l}\text { Potent and competitive B1R antagonist } \\
\text { High affinity }\end{array}$ & Human receptor (no in vivo data) & 139 \\
\hline $\begin{array}{l}\text { Compound } 12 \text { (benzodiazepine-based } \\
\text { structure) }\end{array}$ & Selective antagonist & Human and rat B1R in vitro (equal activity) & 140 \\
\hline Benzo-sulfonylamide componds & Powerful and selective antagonists & & \\
\hline Compound 12 & Hyperalgesia & Rat, dog, orally bioavailable & 142 \\
\hline Compound 11 & Speculative on pain, inflammation and sepsis & $\begin{array}{l}\text { Rabbit aortic preparations, } \\
\text { rabbit jugular vein }\end{array}$ & 141 \\
\hline SSR240612 & Inflammation and hyperalgesia & Mice, rat, oral activity & 143 \\
\hline
\end{tabular}

HOE 140 and D-Arg-[Hyp $\left.{ }^{3}, \operatorname{Igl}^{5}, \mathrm{D}-\mathrm{Igl}^{7}, \mathrm{Oic}^{8}\right]-\mathrm{BK}$, is associated with a strong decrease in affinity in human and rabbit, but not in the mouse B1R, corroborating the previous interpretation.

Efforts to create a third generation of kinin receptor antagonists have evolved towards conventional nonpeptide drug development programs, with oral bioavailability, higher lipophilicity, and lower molecular weight increasingly represented. Various chemical subclasses of nonpeptide B2R antagonists have been discovered: phosphonium compounds, as in WIN64338, WIN62318 (136-138); quinoline and imidazol [1,2-a] pyridine family, such as FR165649, FR167344, FR173657, and FR184280; compound 38; substituted 1,4-dihydropyridines; CP2522; and CP0597 (138). Several nonpeptide B1R antagonists have also been synthesized: PS020990 (139), benzodiazepine-based compounds, such as compound 11 and 12 (140); powerful oxo-sulfonyl agents $(141-143)$.

Some kinin antagonists have also been discovered as natural compounds: martinelline, a pyrroloquinoline alkaloid isolated from the plant Martinella iquitosensis, is the most remarkable example (144). 
Table 2. Pharmacological and clinical application of kinin $\mathrm{B}_{2}$-receptor ligands

\begin{tabular}{|c|c|c|c|}
\hline Ligands & Appllication & Studies & References \\
\hline \multicolumn{4}{|l|}{$\underline{\text { Agonists }}$} \\
\hline $\begin{array}{l}\text { Labradimil ([Hyp }{ }^{3}, \mathrm{Thi}^{5}, 4-\mathrm{Me}^{-\mathrm{Tyr}^{8}} \Psi \\
\left.\left.\left(\mathrm{CH}_{2}-\mathrm{NH}\right) \mathrm{Arg}^{9}\right]-\mathrm{BK}\right)\end{array}$ & $\begin{array}{l}\text { Vascular permeability (blood brain barrier): } \\
\text { adjuvant to chemotherapy of brain tumors }\end{array}$ & $\begin{array}{l}\text { In vivo rodent models } \\
\text { Human: phase II studies on glioma }\end{array}$ & 284 \\
\hline FR190997 & Hypertension & Rat & 283 \\
\hline \multicolumn{4}{|l|}{$\underline{\text { Antagonists }}$} \\
\hline $\begin{array}{c}\text { First generation } \\
{\left[\mathrm{D}-\mathrm{Phe}^{7}\right]-\mathrm{BK}}\end{array}$ & $\begin{array}{l}\text { Low potency, } \\
\text { Antagonist/partial agonist activity }\end{array}$ & $\begin{array}{l}\text { Rat uterus, guinea pig ileum } \\
\text { Rat }\end{array}$ & 133 \\
\hline$\left[\mathrm{Thi}^{5,8}, \mathrm{D}-\mathrm{Phe}^{7}\right]-\mathrm{BK}$ & Potent antagonist, no agonist activity & Rat uterus, guinea pig ileum & 133 \\
\hline \multicolumn{4}{|l|}{ Second generation } \\
\hline \multirow[t]{7}{*}{$\begin{array}{l}\text { HOE } 140 \text { (Icatibant; D-Arg-[Hyp }{ }^{3}, \text { Thi }^{5} \text {, } \\
\left.\text { D-Tic }{ }^{7}, \text { Oic }^{8}\right]-B K \text { ) }\end{array}$} & $\begin{array}{l}\text { High affinity, long-lasting, competitive } \\
\text { activity in but measurable affinity for B1R }\end{array}$ & $\begin{array}{l}\text { Animal models (high affinity for the human, } \\
\text { rabbit, and guinea pig B2R) }\end{array}$ & 134 \\
\hline & No residual agonist effects & & \\
\hline & Resistance to peptidases & & \\
\hline & Acute rhinitis & Human, nasal treatment & 325 \\
\hline & Asthma & Human & 269 \\
\hline & Early stage of inflammation & Rat & 317 \\
\hline & Persistent inflammatory pain & & \\
\hline
\end{tabular}

\footnotetext{
Third generation - Nonpeptide compounds

Phosphonium family:
}

WIN64338 Inactive On human tissues 137

Limited affinity $\quad$ For guinea pig B2R 136

WIN62318 Micromolar binding affinity to human B2R $\quad \begin{aligned} & \text { Identification of the absolute requirement } \\ & \text { for B2R binding affinity: presence of two }\end{aligned}$

for B2R binding affinity: presence of two

positive charges at a distance of about $10 \AA$

separated by a lipophilic residue, playing the

role of $\mathrm{Phe}^{8}$ side chain in the native ligand

\begin{tabular}{|c|c|c|c|}
\hline $\begin{array}{l}\text { Quinoline and imidazol } \\
{[1,2-\alpha] \text { pyridine family: }}\end{array}$ & High B2R affinity and selectivity versus B1R & $\begin{array}{l}\text { Oral activity at doses ranging between } 1 \\
\text { and } 30 \mathrm{mg} / \mathrm{kg} \text { in different tests and species }\end{array}$ & 282,326 \\
\hline FR165649, FR173657, FR184280 & Oral activity on hyperalgesia and inflammation & Rat, mice & 138 \\
\hline FR167344 & $\begin{array}{l}\text { Selective and high potent binding activity } \\
\text { Bronchoconstricition }\end{array}$ & $\begin{array}{l}\text { Guinea pig ileum, human A- } 431 \text { cells } \\
\text { Guinea pigs (oral activity) } \\
\text { Designed as clinical candidate to treat } \\
\text { inflammatory diseases }\end{array}$ & 327 \\
\hline Compound 38 & High affinity & Human B2R & 328 \\
\hline CP2522 & $\begin{array}{l}\text { High affinity } \\
\text { Modeled on CP } 0597 \text { by replacing } \beta \text {-turn } \\
\text { conformation of the peptide by a rigid } \\
\text { 1,4-piperazine ring }\end{array}$ & Human B2R & 138 \\
\hline Substituted 1,4-dihydropyridines & $\mathrm{B} 2 \mathrm{R}$ antagonist at the nanomolar range & Human B2R & 138 \\
\hline Bradyzide & Hypertension Inflammation & $\begin{array}{l}\text { Rodent, orally active, less potent } \\
\text { in human } \mathrm{B} 2 \mathrm{R}\end{array}$ & 292 \\
\hline
\end{tabular}

\section{Natural compounds}

Pyrroloquinoline alkaloid: Martinelline

Affinity for both B1R and B2R at the micromolar range but not selective

L-755807 Inhibition of BK binding to cloned human
$\mathrm{B} 2 \mathrm{R}$ at micromolar range
Alkaloid isolated from the South American tropical plant Martinella iquitosensis

Complex metabolite isolated from a culture $\quad 329$ of the mould Microsphaeropsis sp.

No further pharmacological data

.




\section{Molecular classification}

Distinct B1R and B2R genes coexist in the human genome and, most probably, in the genome of most if not all mammals (129). It is interesting to note that a fish and a bird (the chicken) possess only one type of receptor for kinin homologs and that it is most related to the mammalian B2R, which appears to be ancestral to the B1R (129). Furthermore, the Human Genome project revealed that the human kinin receptor genes are clustered in tandem in the same locus of chromosome 14 (14q32.1 - q32.2), with less than $20 \mathrm{~kb}$ of genomic DNA separating them. This has profound implications for the study of genetic polymorphisms, as a genetic marker in one of the two genes may point out a functional alteration of the other, as this genetic distance is very small and as both genes are likely to be transmitted together vertically (see below).

The molecular definition of the kinin receptor was initiated by the expression cloning of the rat B2R (145) followed by that of the human B1R (146). The degree of aminoacid identity is not very high between the human B1R and B2R sequences (36\%), but they are the most highly related pair, followed by the receptors for angiotensin. The determination of the pharmacological profile of cloned receptors from various species has ended much speculation about the existence of multiple additional receptor subtypes, as it was recognized that the rather large differences in their affinity to agonists and antagonists were a species-related issue.

\subsection{Organization and structure of the receptor genes}

The B1R protein $(40.4 \mathrm{kDa})$ exhibits a seven transmembrane structure typical for GPCR $\left(\mathrm{G} \alpha_{\mathrm{q}}\right.$ and $\left.\mathrm{G} \alpha_{\mathrm{i}}\right)$ and possesses three consensus sites for N-linked glycosylation in extracellular domains, DRY (Asp-Arg-Tyr) and NPXXY (Asn-Pro-XX-Tyr) motifs, and putative sites for phosphorylation and acylation. B1R is not expressed in significant levels in normal tissues (130). The expression of B1R is inducible rather than constitutive. However, exceptions occur in mammals concerning the inducible behavior of B1R. For example, dogs and cats constitutively express the receptor (130).

The human $\mathrm{B} 1 \mathrm{R}$ gene $(B D K R B 1)$ is located on chromosome $14 \mathrm{q} 32.1-\mathrm{q} 32.2$. The gene product consists of 353 aminoacids and approximately $70 \%$ of its overall genomic sequence is homologous to the mouse and the rat $B D K R B 1$ genes. The three-exon structure of the human B1R gene has been determined with the protein sequence being encoded by exon 3 exclusively (147, 148). Critical receptor epitopes for G-protein binding and activation are located on multiple intracellular domains, which are thought to act in concert to form a binding site (149).
As $\mathrm{B} 1 \mathrm{R}$, the $\mathrm{B} 2 \mathrm{R}$ protein structure is typical of that of a GPCR consisting of a single polypeptide chain that spans the membrane seven times, with the amino terminus being extracellular ( $\mathrm{N}$-terminal domain) and the carboxyterminus (C-terminal domain) being intracellular and with three extracellular loops (EL1 - 3) and three intracellular loops (IL1-3). Three consensus sites for $\mathrm{N}$-linked glycosylation are found in extracellular domains. Moreover, the protein contains motifs such as DRY and NPXXY partially embedded in cytosolic receptor domains that are common to most rhodopsin family GPCRs (150), and the C-terminal tail contains serine and threonine residues that are putative phosphorylation sites and cysteines that are putative sites for acylation.

The B2R has been identified in most tissues and is particularly present on endothelial cells, smooth muscular cells, fibroblasts, mesengial cells, some neurons, astrocytes, and polynuclear neutrophils (151). Its gene expression level is constitutive. The human $B D K R B 2$ gene product consists of 391 aminoacids and the three-exon structure of the gene is also located on chromosome 14 (152) but about $12 \mathrm{~kb}$ upstream from $B D K R B 1$ (153). About $80 \%$ of the human BDKRB2 gene is homologous to the mouse and rat $B D K R B 2$ gene. The human $B D K R B 1$ and $B D K R B 2$ are also similar to each other with $36 \%$ genomic sequence homology. The mRNA coding for the B2R $(4 \mathrm{~kb})$ is large compared with that of B1R $(1.4 \mathrm{~kb})$.

\subsection{Receptors expression and regulatory elements in gene promoters}

Expression of the B1R is up-regulated following some types of tissue injury, and its relationship to pathology is therefore obvious. Exposure to bacterial endotoxins or cytokines, tissue trauma, inflammation, anoxia (130), and myocardial infarction (154) are examples of inducing stimuli. IL- $1 \beta$ and tumor necrosis factor (TNF)- $\alpha$ induce the expression of the B1R in vitro $(155,156)$ and in vivo $(157,158)$.

Cytokine-induced B1R expression is mediated by specific MAP-kinase pathways (notably, p38 and JNK) and nuclear factor- $\kappa \mathrm{B}(\mathrm{NF}-\kappa \mathrm{B})(159-162)$. Inflammatory induction of $\mathrm{B} 1 \mathrm{R}$ expression correlates with $\mathrm{NF}-\kappa \mathrm{B}$ stimulation in various systems $(163,164)$. Studies on the human embryonic IMR-90 cell line led to the hypothesis of autoregulation of the B1R; stimulation of either the B1R or B2R in these cells led to the increased expression of the B1R (mRNA, protein) (165, 166). However, this model may not be generally applicable, as these permissive cells produce autocrine IL- $1 \beta$ in response to the stimulation of various GPCRs (167) and as kinin receptor stimulation does not up-regulate 
B1R expression in primary vascular cells (cultured smooth muscle cells) or in vivo, following the activation of the contact system in rabbits using dextran sulfate (168). Evidence of the role of the transcription factor AP-1 in B1R expression has been derived from a construction composed of the $1.8 \mathrm{~kb}$ core promoter, exon 1 , and $1.5 \mathrm{~kb}$ of intron 1 , exon 2 , intron 2 , and a luciferase reporter (169).

The expression of B2R is up-regulated not only by BK but also by cAMP and phorbol esters (170). Multiple potential binding sites have been identified recently in the B2R promoter (171): GATA-1, CCAAT displacement protein, E2F, Egr2, IL-6 activator protein, NF- $\kappa \mathrm{B}$, $\mathrm{p} 53$, estrogens. IL-1 $\beta$ increases both the number of $\mathrm{B} 2 \mathrm{R}$ as well as the level of B2R mRNA through a prostanoid and cAMP dependent pathway, which may lead to protein kinase A activation of the transcription factor cAMP response element-binding protein (172).

\subsection{Second messengers}

Signal transduction of kinin receptors activates several second messenger systems, depending on cellular type, via the activation of G-proteins (Fig. 2).

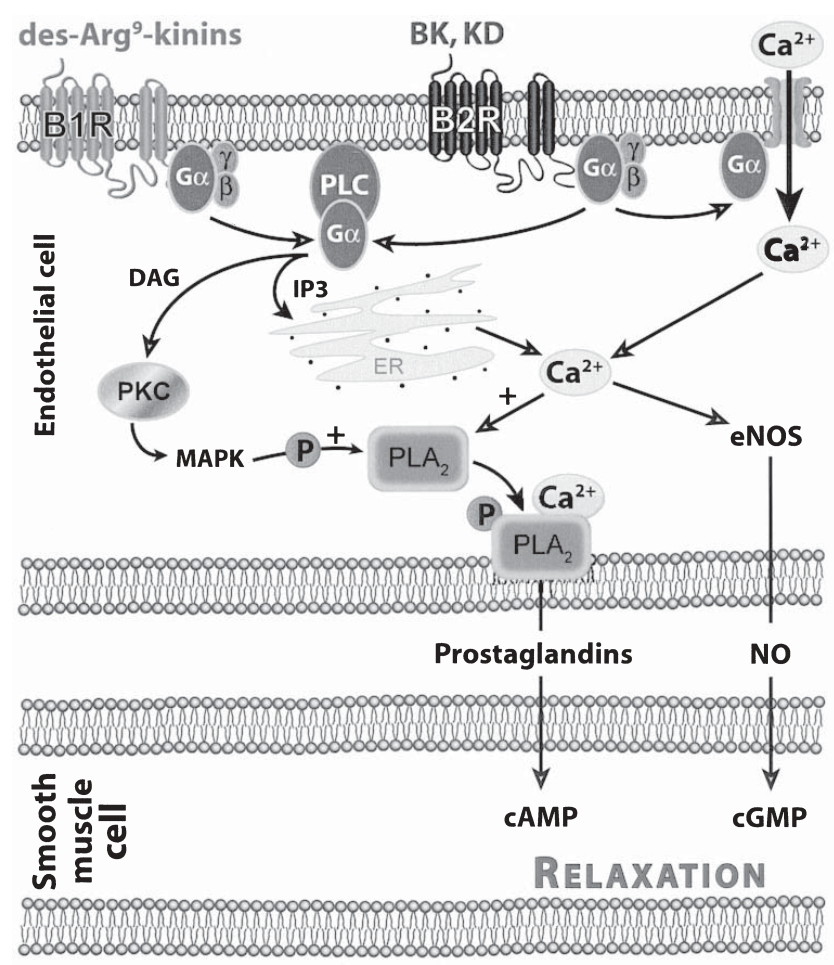

Fig. 2. Kinin receptors and their signaling pathways. Schematic representation of $B_{1}$ and $B_{2}$ receptors and the second messengers released by their activation. PLC: phospholipase C; ER: endothelial reticulum; DAG: diacylglycerol; IP3: inositol 1,4,5-triphosphate; $\mathrm{PLA}_{2}$ : phospholipase $\mathrm{A}_{2}$; NO: nitric oxyde; eNOS: endothelial NO synthase.
Activation of adenylyl cyclase or guanylyl cyclase is a transduction mechanism that leads to the production of cAMP and to cGMP, an efficient vasodilatory mechanism in vascular smooth muscle. However, the kinin receptors, coupled to $G_{q}$ and $G_{i}$ proteins, are only indirectly linked to cyclic nucleotide signaling: via the endothelial production of $\mathrm{NO}$, itself capable of activating the soluble guanylate cyclase in neighboring cell types or via the production of prostaglandins (PGs) $\mathrm{I}_{2}$ or $\mathrm{E}_{2}$ that possess $\mathrm{G}_{\mathrm{s}}$-protein-coupled receptors. The activation of ionic channels and of PLs $\mathrm{A}_{2}, \mathrm{C}$, and $\mathrm{B}$ also play a role in kinin receptor signaling. PLC products, inositol 1,4,5-triphosphate and diacylglycerol (DAG) (173), are respectively responsible for transporting calcium into the cytosol from intracellular stores and for protein kinase $\mathrm{C}$ translocation from the cytosol to the plasma membrane. $\mathrm{Ca}^{2+}$ mediates the activation of endothelial NO synthase (eNOS) and ultimately the production of NO in endothelial cells (174) and stimulation of $\mathrm{PLA}_{2}$ (129). Arachidonic acid could also be liberated from cellular membrane phospholipids by the action of $\mathrm{PLA}_{2}$ and lead to $\mathrm{PG}$ production. In addition to these classical pathways, B2R can activate signaling proteins that possess cytoplasmic tyrosine kinase activity (175). The activated B2R also transiently promotes tyrosine phosphorylation of MAP-kinase (176), PLC (177), and Hsp90 (178) and has a direct interaction with neuronal and eNOS allowing the control of NOS phosphorylation and NO production $(179,180)$. Furthermore, BK activates caveolae-associated Janus-activated kinase/signal transducers and activators of the transcription (JAK/STAT) pathway in endothelial cells (181). Tyrosine kinases of the JAK family phosphorylate STAT proteins that directly regulate transcription of specific genes.

B1R also interacts directly with $\mathrm{G} \alpha_{\mathrm{q}}$ and $\mathrm{G} \alpha_{\mathrm{i}}$ proteins and recruits essentially the same signaling pathways as the B2R. Although the B1R and B2R seem to couple to similar cellular signal transduction pathways, the patterns of signaling are different in terms of variation of $\mathrm{Ca}^{2+}$ concentration (in duration and in intensity, see below). B1R is principally associated with PLC activation and with the phosphoinositol pathway, but also acts through $\mathrm{PLA}_{2}$ and the MAP-kinase (130).

\subsection{Receptor desensitization}

Besides their pharmacological differences, B1R and B2R also display important differences in their susceptibility to desensitization. When activated by an agonist, B2R undergoes to a rapid desensitization (182), involving phosphorylation of specific Ser and Tyr residues in the receptor large C-terminal domain (129).

Another mechanism that may participate in B2R 
desensitization involves BK-promoted transient association of $\mathrm{G} \alpha_{\mathrm{q}}$ and $\mathrm{G} \alpha_{\mathrm{i}}$ with in caveolae (183). B2R activation leads to functional desensitization which is associated with receptor phosphorylation/dephosphorylation and endocytosis/surface re-expression cycles (184). Cys $^{324}$ in the cytoplasmic carboxyl terminus of the human B2R appears to play a role in agonist-induced internalization. It is true that $\mathrm{B} 2 \mathrm{R}$ down-regulation is observed in some forms of intense and chronic inflammation, but the mechanism is unknown; proteases present in the extracellular fluid have been shown to destroy a form of recombinant $\mathrm{B} 2 \mathrm{R}$, thus providing a possible mechanisms for inflammatory B2R downregulation (185).

The B1R differs from the B2R in that it is desensitized only to a very limited degree and human B1R is not phosphorylated to any significant degree either in the absence or presence of agonist (186). The receptor lacks any Ser and Tyr residues in the C-terminal tail. This lack of regulation can contribute to the constitutive activity of the receptor. Its agonist-induced translocation to caveolae-related rafts without internalization has been proposed $(129,187)$. This type of reversible translocation may be of interest for a subset of the signaling pathways activated by kinin receptors, as rafts are rich in signaling molecules.

\section{Part II: The Kallikrein-Kinin System: Pathophysiology and Pharmacological Target}

\section{I- The Kinin Forming System in Plasma}

\section{Genetic defects}

\subsection{Defects of the contact system components}

Genetic deficiencies have been reported for $\mathrm{HK}$ (William trait), PKK (Fletcher trait), and factor XII (Hageman trait) (188). These defects do not lead to bleeding tendencies. Deficiencies of factor XII, forever associated with thromboembolic events, suggest a relationship between depressed factor XII-dependent fibrinolysis and cardiovascular diseases. Quantitative and qualitative defects of plasminogen have also been associated with thromboembolism diseases $(19,189)$.

\subsection{Defect in the control of the contact system: C1 inhibitor (C1INH)}

\subsubsection{Definition}

Patients who present a genetic deficiency in C1INH suffer from hereditary angioedema (HAE). HAE attacks involve the activation of two pathways controlled by this serpin: the classical complement and the contact system pathways. The latter is responsible for the release of vasoactive BK (190), which is probably the main but not the sole mediator responsible for the increased vascular permeability that results in angioedema (AE) $(191-194)$. The activation of other pathways could also be involved in the pathogenesis of HAE. In fact, Cugno et al. (1993) reported that generation of BK is associated with activation of fibrinolysis during acute attacks of HAE (51).

The prevalence of HAE is believed to be between $1 / 10,000$ and $1 / 50,000$ people worldwide (195). HAE is traditionally described as Type I (HAE-I, 85\% of patients), which is characterized by a defective or absence in gene production of C1INH and Type II (HAE-II, 15\% of patients), which is characterized by a functionally impaired C1INH (196). C1INH deficiency is heterogeneous at the gene level and is caused by subtle changes affecting one or several nucleotides, large deletions or duplications. These modifications have been discussed recently by Agostoni (190). In either case, HAE is associated with low functional activity of $\mathrm{C} 1 \mathrm{INH}$, low levels of $\mathrm{C} 4$, and normal levels of $\mathrm{C} 3$.

\subsubsection{Pathophysiology}

A murine model of HAE contributed to support the hypothesis that $\mathrm{BK}$ mediates HAE. In this model, mice heterozygous and homozygous for a gene coding for C1INH demonstrated increased permeability and depletion of $\mathrm{HK}$. When treated with a specific plasma kallikrein inhibitor or a B2R antagonist, the increased vascular permeability was completely reversed (197).

Besides HAE, acquired forms of angioedema (AAE) have been described. These AAE, characterized by normal immunoreactive and functional $\mathrm{C} 1 \mathrm{INH}$ levels, are associated with drug therapy, such as with estrogens and metallopeptidase inhibitors (ACE inhibitors (ACEi) and vasopeptidases inhibitors (VPi), see below) (198). They also occur during immunoproliferative and autoimmune diseases. Finally, idiopathic forms of AAE have also been reported (190).

\subsubsection{Treatment of $\mathrm{HAE}$}

The purpose of this treatment is to inhibit the release of vasoactive peptides among which is BK or to block their proinflammatory effects (Fig. 3).

1.2.3.1 Serine proteases inhibitors: $\mathrm{C} 1 \mathrm{INH}$ and aprotinin are two serpins used in the treatment of HAE (199).

A) Aprotinin and aprotinin-like drugs: Aprotinin is a naturally occuring 58 aminoacid serpin isolated from bovine lung that inhibits serine proteases with a particularly high affinity for plasma kallikrein and plasmin (200). Inhibition of plasma kallikrein, which triggers the release of $\mathrm{BK}$ during the contact system activation, 


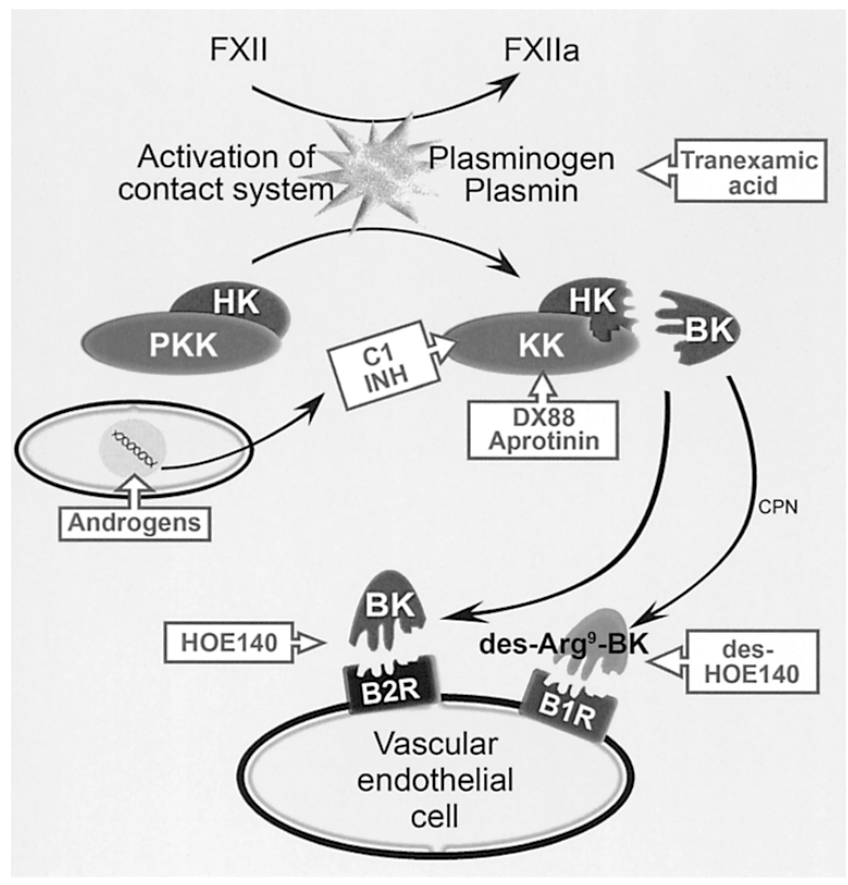

Fig. 3. Pharmacological targets to modulate the kallikrein-kinin activity. Tranexamic acid inhibits fibrinolysis and DX88 and C1INH inhibit the serine activity of plasma kallikrein, although androgens stimulate the synthesis of C1INH. $\mathrm{B}_{1}$ and $\mathrm{B}_{2}$ antagonists block the activation of their respective receptors.

could lead to a decreased release of BK during the HAE attack. This inhibition of plasmin, but also of other coagulation factors like protein $\mathrm{C}$, is probably responsible for the effectiveness of aprotinin in the treatment of bleeding of different ethiologies (disseminated intravascular coagulation, extracorporeal circulation during cardiac surgery).

An aprotinin-like inhibitor isolated from human urine, ulinastatin, is approved for intravenous therapy in Japan (200). Nafamostat is a synthetic inhibitor of kallikrein and coagulation factors enzymes $(201,202)$ by working as an inverse substrate.

B) CIINH, Berinert ${ }^{\circledR} P$ : Severe HAE-attacks are currently treated by intravenous injection of pasteurized C1INH purified from human blood plasma $(\mathrm{pdC} 1 \mathrm{INH}$; Berinert $^{\circledR}$ P) (203). This treatment is efficacious as it inhibits the activation of the contact system that typically occurs during HEA attacks.

Recombinant human C1INH has also been developed and is currently being tested in a clinical trial.

1.2.3.2 DX88: DX88 is a synthetic kallikrein-inhibitor, based on a recombinant Kunitz-domain (a serine protease inhibitor domain) produced by a phage display technology. In vivo, the drug effectively reverses the increased vascular permeability in C1INH-deficient mice at very low intravenous doses $(193-197,204)$.
As DX88 bypasses the C1INH pathway, it presents also a potential interest in the treatment of AAE. Clinical trials show that the drug was generally well tolerated and improved the clinical symptoms of HAE within the first $4 \mathrm{~h}$ following the laryngeal attack.

1.2.3.3 Attenuated androgens: Danazol $^{\circledR}$, Stanozolol $^{\circledR}$ : Danazol and stanozolol are synthetic analogues of 17- $\alpha$ alkylated androgen that were shown to considerably reduce the number HAE attacks when used for longterm prophylaxis. As testosterone derivatives, they maintain a residual hormonal activity whose clinical relevance is dependent on the dose. High doses of attenuated androgens $(400-600 \mathrm{mg} /$ day) correct the biochemical defect of HAE, normalizing $\mathrm{C} 1 \mathrm{INH}$ and $\mathrm{C} 4$, usually leading to complete disappearance of $\mathrm{AE}$ crises after a month of treatment (205).

The mechanism of action of attenuated androgens is probably related to an increase in protein synthesis, as an increase in C1INH plasma levels is observed (206), but the mechanism has not yet been elucidated (196), and the effect on metallopeptidases responsible for the inactivation of kinins has not been documented.

1.2.3.4 Antifibrinolytic drugs: tranexamic acid (Transamin $^{\circledR}$, Cyklokapron $^{\circledR}$, Exacyl $^{\circledR}$, Cyklo-f $\left.^{\circledR}\right)$ : Tranexamic acid (4-(aminomethyl)cyclohexanecarboxylic acid) is a synthetic lysine derivative that forms a reversible complex with plasminogen at the lysine binding site and thus prevents fibrin degradation by plasmin without any effect on overall blood coagulation parameters. The reduction in plasminogen binding to fibrin appears to result in a decrease in the production of t-PA by endothelial cells or an increase in the rate of its clearance (207).

Tranexamic acid is presented in a variety of formulations for oral or intravenous use. The oral bioavailability has a rate of approximately $34 \%$ and therapeutic plasma concentrations reach $5-10 \mathrm{mg} / \mathrm{L}$ (208). A greatest efficacy against HAE was reported when the drug was taken in a long-term prophylaxis $(205,207,208)$.

1.2.3.5 B2R antagonists: HOE 140 (Icatibant ${ }^{(B)}$ or $\boldsymbol{J E 0 4 9}^{\circledR}$ ): Icatibant is currently tested in clinical trials for treatment of HAE. A phase II proof-of-concept study in HAE was concluded with positive clinical results. High bioavailability (about 90\%), combined with a low variability and a maximal concentration reached after about $30 \mathrm{~min}$, has been demonstrated with a subcutaneous formulation, which can be self-administrated at a very early stage of an HAE attack. Icatibant has also shown therapeutic benefit in refractory ascites in liver cirrhosis as well as preclinical models for severe burn injuries (209). 


\section{Acquired diseases}

\subsection{Sepsis}

Although the pathophysiology of sepsis remains largely unknown, experimental and clinical data point to a role of kinins in sepsis. First, in vitro, different bacterial strains responsible for sepsis interact with the contact system of plasma leading to the release of BK. In vivo, the factors of the contact system are consumed in plasma of patients suffering from sepsis. Recently, a significant increase of plasma BK was also measured in plasma of patients suffering from $S$. aureus sepsis while simultaneously treated with an ACEi (210). On the other hand, the injection of LPS from E. Coli into the dorsal skin of rats caused a dose-dependent increase in vascular permeability and this increase caused by LPS was attenuated by pretreatment with the B2R antagonist HOE 140 (211). These observations could open a new area for the clinical application of B2R antagonists. However, and until now, the behavior of B1R agonists (des-Arg ${ }^{9}-\mathrm{BK}$ and des-Arg ${ }^{10}-\mathrm{KD}$ ) in septic patients and the effect of sepsis on the kinin forming capacity of fibrinolysis have not been documented.

Another therapeutic approach of sepsis could be the use of the pentapeptide Arg-Pro-Pro-Gly-Phe, the stable metabolite of BK (212). In fact, recent studies have shown that this pentapeptide is able to increase significantly the survival of rats treated with LPS (213) and to inhibit the thrombin-induced platelet aggregation (214).

\subsection{Anaphylactoid and severe hypotensive reactions}

Contact system activation is also responsible for the anaphylactoid reaction (AR) in hemodialysis and severe hypotensive reaction (SHR) during blood product transfusion in patients simultaneously treated with an ACEi (see below) $(215,216)$.

\section{Antithrombolytic treatment and kinins}

A complex and dual relationship exists between the fibrinolysis and the kinin system.

The application of recombinant technology has allowed large-scale production of t-PA and its use for thrombolytic therapy. Wide use of recombinant t-PA (rt-PA) for thrombolysis in patients with myocardial infarction stimulated intensive studies of structure function relationships of t-PA and development of mutant forms of t-PA with improved pharmacokinetic properties, that is, with prolonged lifetime in circulation and increased resistance to inhibitors and to cleavage by plasmin (46). However, by stimulating the plasmin formation, thrombolytic drugs not only dissolve the clot but also activate factor XII, the complement cascade and the kinin system $(20,217)$. In vitro, rt-PA at a therapeutic concentration generates significant quantities of
BK and des-Arg'-BK from human plasma, and this kinin-forming activity depends on the activation of plasmin which hydrolyzes HK, independently of the activation of factor XII and PKK (47).

In addition, $\mathrm{BK}$ stimulates the exocytosis of t-PA from the vascular endothelium. Studies using the B2R antagonist HOE 140 indicate that $\mathrm{ACEi}$ also increase endogenous t-PA release through a B2R-dependent pathway (218). This potentiating effect of ACEi on fibrinolysis constitutes a new aspect of the cardioprotection by ACEi.

\section{II- The Metabolism of Kinins}

Until now, among the kinin metabolizing enzymes, only ACE has been a clinically exploited pharmacological target. However, the effectiveness of this class of metallopeptidase inhibitors has opened research in the development for more potent inhibitors that inhibit two metallopeptidases, namely ACE and NEP.

\section{ACE: pathophysiology}

The broad spectrum of substrates for ACE and its wide distribution throughout the body indicates that this enzyme, in addition to an important role in cardiovascular homeostasis, may be involved in additional physiologic processes such as neovascularization, fertilization, atherosclerosis, kidney and lung fibrosis, myocardial hypertrophy, inflammation, and wound healing (66). The deleterious effects of ACE on the cardiovascular system were initially thought to be a consequence of the formation of Ang II, which initiates a cascade of events involving increased free radical production and vascular smooth muscle cell proliferation (79). However, as BK is much more readily hydrolyzed by ACE than Ang I, the hydrolysis of BK may also contribute to this phenomenon (219).

ACE2 has been implicated in cardiovascular pathology, and the generation of ACE2-knockout mice revealed that the enzyme is an essential regulator of heart function $(67,220)$.

\section{ACE inhibitors (ACEi)}

The inhibitors of ACE have emerged as a first-line therapy for a range of cardiovascular and renal diseases, including hypertension, congestive heart failure, myocardial infarction, and diabetic nephropathy. The first clinically used ACEi was captopril $\left(K_{\mathrm{i}}=1700 \mathrm{pM}\right)$. Numerous other more potent dipeptide and tripeptide inhibitors, which bind to both catalytic sites in somatic ACE have been synthesized subsequently for clinical use in humans (61).

The inhibition of ACE activity is reported to improve 
endothelial function and to stimulate vascular remodeling, as well as attenuate the progression of arteriosclerosis and the occurrence of cardiovascular events in humans $(221,222)$. The identification of ACE as a signalling molecule that can be activated by the binding of ACEi may account for some of the beneficial effects of this class of compounds on the cardiovascular system.

Since their discovery, a series of large, multicentre clinical randomized trials have definitively established the very important role of ACEi in cardiovascular medicine (223).

\subsection{Multicenter clinical randomized trials}

Numerous clinical trials have established the role of ACEi in ischemic heart disease, particularly after acute myocardial infarction (MI). Early trials (SAVE, TRACE, AIRE) focused on patients with left ventricular dysfunction (224-226). More recent trials (HOPE, PROGRESS, EUROPA) have demonstrated a benefit of ACEi in preventing cardiovascular events even in patients with normal ejection fraction.

The HOPE study, an international randomized trial, showed that ramipril $\left(K_{\mathrm{i}}=7 \mathrm{pM}\right)$ was beneficial in a broad range of patients without evidence of left ventricular systolic dysfunction or heart failure who are at high risk for cardiovascular events (222). The EUROPA study extended the findings of HOPE to a group of lower risk patients with coronary artery disease frequently seen in clinical practice. PROGRESS demonstrated that lowering blood pressure with an ACEi and diuretic reduced strokes and cardiovascular events in stroke patients. While some of the effect of ACEi may be attributable to blood pressure lowering, the mortality benefit is unequivocal. In addition, ACEi prevents the progression of renal injury in diabetes (227) and a number of diseases and reduces death due to $\mathrm{MI}$ in diabetic population (228). Taken together these studies present strong evidence that patients with evidence of stable coronary heart disease, vascular disease, and/or diabetes (plus one further risk factor), regardless of left ventricular function, should be treated with an ACEi. The challenge now is to translate this evidence-based therapeutic management into cardiological practice (229).

The mechanism by which ACEi reduce cardiovascular mortality is the subject of intense investigation. ACEi have been shown to improve endothelial function, a marker of future cardiovascular events. While some investigators have suggested that ACEi with higher tissue affinity for somatic ACE may have a greater impact on cardiovascular mortality, no comparative trials have been conducted.

\subsection{Role of BK in the cardiovascular effects of $A C E i$}

The evidence for a contribution of kinins (mainly $\mathrm{BK}$ ) in the cardiovascular effects of ACEi is essentially of pharmacological nature. These results have been extensively reviewed elsewhere (230). In various experimental models, in vitro, ex vivo, and in vivo, ACEi mimic and potentiate the pharmacological effects of BK, which can be suppressed by a B2R antagonism, mainly by HOE 140 (Icatibant). These observations have been made using cell models, where an ACEi stimulates the $\mathrm{NO}$ and prostacyclin $\left(\mathrm{PGI}_{2}\right)$ production triggered by BK. In vivo, Icatibant has been shown to suppress the antihypertensive, antihypertrophic, and antiproliferative effects of ACEi to a variable extent, depending on the experimental model. The effect on the antihypertensive effects of ACEi is more controversial and depends on the experimental model. In hypertensive subjects, a short-term hypotensive effect of captopril was abolished at least in part by Icatibant (231). Several but not all studies indicate that $\mathrm{BK}$ contributes to the effects of chronic ACEi in patients with congestive heart failure.

The contribution of endogenous kinins in these pharmacological effects is more controversial, and it is still not clear, at the present time, which part is due to the B1R and B2R agonists in the pharmacological effects. In fact, depending on the animal model, ACEi potentiate either the concentration of BK or des-Arg 9 BK. These apparent discrepanties could be the result of varying importance of other metallopeptidases responsible of the metabolism of kinins (72).

\section{Vasopeptidase inhibitors (VPi)}

The VPis possess the ability to inhibit simultaneously two membrane-bound zinc metalloproteases, ACE and NEP, with similar nanomolar inhibitory constants (232). Omapatrilat was the first of this new class of drugs. This dual inhibitor has been evaluated clinically for the treatment of hypertension, heart failure, and renal disease.

\subsection{Multicenter clinical randomized trials}

Preclinical (233) and early clinical studies conducted with omapatrilat were very promising. Indeed, omapatrilat appeared to be a potent antihypertensive agent with favorable effects on cardiac function in heart failure patients $(234,235)$. In contrast to these early studies, the large clinical trials were more disappointing.

The results of the Omapatrilat Cardiovascular Treatment Versus Enalapril (OCTAVE) trial suggested that use of a more efficacious monotherapy such as omapatrilat can result in greater blood pressure reductions, but at the price of an AE rate more than threefold 
higher than that of an ACEi in the overall population (see below) (236).

In The Omapatrilat Versus Enalapril Randomized Trial of Utility in Reducing Events (OVERTURE), the patients with chronic heart failure and hypertension treated with omapatrilat had a reduced morbidity and mortality when compared with enalapril. AE was also more common with omapatrilat (236-238).

\subsection{Role of kinins in the cardiovascular effects of VPi}

The protective effect of omapatrilat on BK degradation on both cardiomyocytes and endothelium, two target sites for metallopeptidase inhibitors, has also been compared to that of ACEi $(239-241)$. These studies have shown the complexity of the different metabolic pathways, whose importance varies according to the tissue but also the nature of the pathophysiological background. As an example, Fig. 4 illustrates the influence of insulin on the protective effect of an ACEi and a VPi on the cardiac metabolism of BK in experimental type I diabetes. Hence, BK may also be an important mediator of this new class of drugs. The effects of a single inhibitor of both ACE and NEP, resulting in an indirect activation of the $\mathrm{B} 2 \mathrm{R}$, could be responsible for additional beneficial therapeutic effects

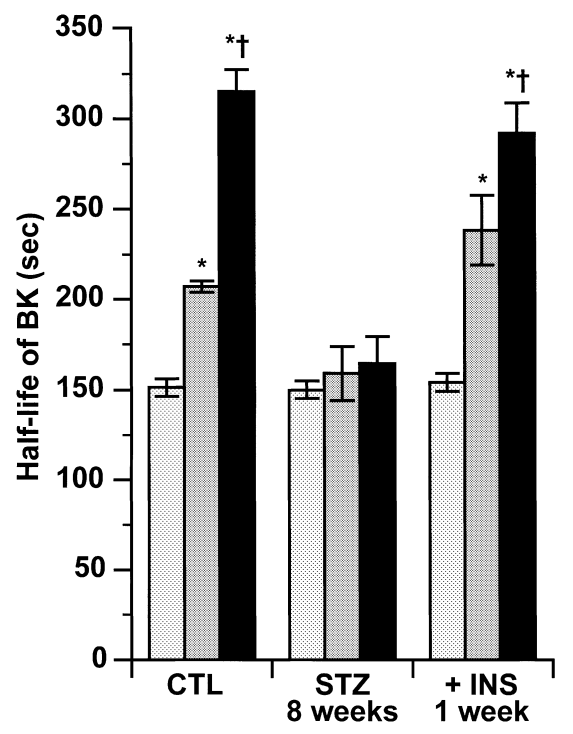

Fig. 4. Influence of insulin on the cardiac metabolism of exogenous BK in experimental type I diabetes. The half-life of exogenous BK incubated with heart membranes from Sprague-Dawley control rats (CTL), streptozotocin (STZ)-treated rats 8 weeks post-injection and STZ-treated rats before and after (7 days) insulin administration (+INS-1 week). Membranes were incubated with exogenous BK without enzymatic inhibitor (shade) or in presence of enalaprilat (grey) or omapatrilat (black). Values are means \pm S.E.M. ${ }^{*} P<0.05$ versus without inhibitor; ${ }^{\dagger} P<0.05$ versus enalaprilat. (Reproduced with permission from P. Leclair, MSc Thesis, p. 79, Université de Montréal, 2000) of VPi such as omapatrilat $(242,243)$.

\section{Kinins and side effects of metallopeptidase inhibitors}

Despite their clinical effectiveness, ACEi can cause chronic and acute side effects. The best known chronic side effect is a non-productive cough. Although some experimental and clinical evidences suggest a role of BK in the pathophysiology of this effect, no definitive arguments exist for such a role.

The nature of acute side effects of ACEi depends on the clinical context. Angioedema has been reported in hypertension and heart failure, but also in stroke patients during fibrinolysis with rt-PA (244). AR occur in patients dialysed with a negatively charged membrane (119). Finally, SHR have been described during blood product transfusion (216). In these cases, the majority of the reactions occurred during transfusion of blood components administered through a negatively charged bedside leukocyte reduction filter. A similar reaction also occurs during LDL and plasmapheresis (245).

The incidence of these acute side effects has traditionally been around $0.1 \%$ to $0.2 \%$. However, this incidence must be revised in light of the OCTAVE study $(236,246)$. This study has shown an incidence of AE with enalapril equal to $0.68 \%$ in Caucasian hypertensive patients. This incidence was still higher in African Americans $(1.62 \%)$ and in smokers $(0.81 \%)$, whereas patients with diabetes had lower rates of AE. This study showed an increased incidence of $\mathrm{AE}$ associated with omapatrilat in Caucasians $(2.17 \%)$, African Americans (5.54\%), and smokers (3.93\%). These results are important because they highlight 3 factors: the presence of inflammation (smokers), the genetic aspect (African Americans), and the nature of the metallopeptidase inhibitor that inhibits one or two peptidases, specifically or non-specifically.

In fact, acute side effects of ACEi and, by extension, of other metallopeptidase inhibitors (VPi) could result in the meeting of at least 3 different factors. The first one is the presence of a drug that inhibits specifically ACE (or ACE plus NEP) but could also non-specifically inhibit other enzymes involved in the metabolism of kinins, such as APP or CPN. The second factor may be a pathophysiological or physicochemical trigger for the release of kinins. It has been identified as the negatively charged surface in AR and as the negatively charged filter in SHR. The triggering factor remains unknown in $\mathrm{AE}$ but could be linked to the inflammatory status, as suggested by the higher incidence in smokers. The third factor could be intra- or inter-individual genetic or environmental factors that effect non-ACE inhibitor mediated pathways metabolizing vasoactive peptides such as the kinins. 
We have investigated the metabolism of endogenous kinins from the plasma of patients who developed $\mathrm{AE}$ while being treated with an ACEi. While we found no abnormality in the metabolism of BK, Caucasian patients with a history of AE exhibited slower degradation of des-Arg ${ }^{9}-\mathrm{BK}$, correlating with a decreased activity of plasma APP $(247,248)$. This anomaly could also be observed in patients who presented an AR (119) or a SHR $(245,249)$. We hypothesized that the accumulation of the B1R agonist could be responsible for the symptoms that characterize AR and SHR, but our observations cannot be related to the local inflammatory reaction that characterizes $\mathrm{AE}$.

As no inhibitor of APP is present in plasma (119), we investigated the genetic aspect of AE. A recent report provides evidence that variable APP activity in humans is partially regulated by genetic factors. From data ascertained from 8 Caucasian kindreds whose probant suffered either an $\mathrm{AE}$ whilst being treated with an ACEi, we estimated that $34 \%$ of the phenotypic variation results from genetic differences in the linkage analysis. We described two sequence variations, a nonsense mutation resulting in a truncated protein and a potentially regulatory single nucleotide polymorphism (SNP) that segregated with reduced plasma APP activity, suggesting an increased susceptibility to ACEi associated acute side-effect (250). These findings do not mean that this active metabolite, des-Arg'-BK, is necessarily the only mediator of AE; a local release of neurokinins or a decrease in DPP IV activity (substance P-degrading enzyme) seems to be associated with this potentially life-threatening side effect (251), particularly in African Americans. The precise mechanism responsible for ACEi-associated AE is not known.

\section{III- Kinin Receptors}

\section{Receptor polymorphisms and pathology}

The potential role of kinin receptors in human disease is derived from studies evaluating kinin receptor polymorphisms, measurement of differences in kinin receptor expression level, and detection in differences in receptor functions. However, reports concerning a correlation between SNP in kinin receptor genes and complex pathologies should be carefully interpreted. Usual analysis involves a statistical comparison between case and control populations. Nevertheless, this method does not always take in account the influence of a nearby gene rather than the gene of interest or the possibility of a true relationship between a SNP with a disease which were not at first directly correlated. The specific situation of the kinin receptor locus is particularly problematic in this respect: as both kinin receptor genes lay very close to each other in the same locus, a genetic marker in one of them may point out to a functional alteration of the other; there is some experimental support for this idea (252). Further pharmacological studies, appropriate family-based designs, or case-control designs analyzing haplotypes rather than single SNP (253) should also be used to demonstrate the predicted interrelation.

Many polymorphisms of $\mathrm{B} 2 \mathrm{R}$ and $\mathrm{B} 1 \mathrm{R}$ have been described (254). Some of them have been related to pathophysiological events.

\subsection{Polymorphism of B2Rs}

Left ventricular hypertrophy and cardiomyopathy are some of the adverse effects of hypertension. These pathologies have been linked to kinin receptors (255).

\subsection{1 +9/-9, exon 1 polymorphism}

A $+9 /-9$ exon 1 polymorphism of the B2R was strongly associated with the left ventricular growth response among normotensive white males undergoing a ten-week physical training program. Individuals with the lowest levels of B2R ( $+9 /+9$ genotype) and the highest levels of ACE (DD genotype) had the greatest increase in left ventricular mass (256). Subjects with B2R $+9 /+9$ genotype showed less left ventricular mass regression compared with other genotypes. B2R (+9/-9) polymorphism was also shown to be significantly associated with higher skeletal muscle metabolic efficiency and with endurance in athletic performance (257).

The $(-9 /-9)$ genotype of B2R exon 1 was also examined for the contractile response of human umbilical veins to stimulation with kinins (252). This polymorphism was associated with increased contractile efficiency of the B1R agonist, suggesting that the B2R gene may be in linkage disequilibrium with the $\mathrm{B} 1 \mathrm{R}$ gene.

Cardiovascular risk and increase in blood pressure associated with hypertension are also influenced by the presence of B2R $(+9)$ allele, an effect not identified in individuals homozygous for B2R (-9) (258). This suggests a role of $\mathrm{B} 2 \mathrm{R}$ in human coronary vascular disease.

B2R (+9/-9) polymorphism was significantly associated with diabetic nephropathy (259).

The B2R (-9) allele has been associated with the most symptomatic cases of C1INH deficiency (hereditary angioedema with angioedema crises) and thus is proposed to modulate in a dominant manner the phenotype of the basic genetic defect of this disorder (130). However, this polymorphism did not predict the incidence of the most common side effect of ACEi, the non-productive cough (260). 


\subsection{2 $\left(C^{-58} \rightarrow T\right)$, promoter region polymorphism}

Several studies have detected a significant association between the B2R $\left(\mathrm{C}^{-58} \rightarrow \mathrm{T}\right)$ polymorphism and hypertension. A consistent finding that the $\mathrm{C}^{-58}$ allele has higher frequency in hypertensive individuals compared to normotensive individuals has been reported in various populations $(261-263)$. The allele frequencies are similar in Caucasians and Afro-American populations, whereas the $\mathrm{T}$ allele is slightly more frequent in the Japanese.

The genotypic and allelic frequencies of $\left(\mathrm{C}^{-58} \rightarrow \mathrm{T}\right)$ polymorphism of general hypertensive subject were analyzed (264). The frequencies of the TT genotype and the $\mathrm{T}$ allele of $\left(\mathrm{C}^{-58} \rightarrow \mathrm{T}\right)$ are higher in the subjects with cough than in subjects without cough. Moreover, $\mathrm{T}^{-58}$ was found to have a higher transcription rate than that of $\mathrm{C}^{-58}$. The high transcriptional activity of the B2R promoter might be involved in the occurrence of ACEi-related cough.

\subsection{3 $\left(C^{181} \rightarrow T\right)$, exon 2 polymorphism}

Presence of the nonsynonymous coding region $\mathrm{B} 2 \mathrm{R}$ exon $2\left(\mathrm{C}^{181} \rightarrow \mathrm{T}\right)$ was associated with increased contractile potency in response to stimulation with BK consistent with the enhanced in vitro potency of BK at the $\operatorname{Arg}^{14} \rightarrow$ Cys mutant receptor (252) and with significantly lower systolic and diastolic blood pressure (265).

\subsection{Polymorphisms of B1Rs: $\left(G^{-699} \rightarrow C\right)$ substitution}

Cardiovascular risk and increase in blood pressure associated with hypertension are influenced by the presence of B1R $\left(\mathrm{G}^{-699}\right.$ substitution) allele, an effect not identified in the presence of the homozygous B1R (C $\mathrm{C}^{-699}$ substitution) allele (258). This suggests a role of $\mathrm{B} 1 \mathrm{R}$ in human coronary vascular disease.

The B1R polymorphism consisting of a single base substitution $\left(\mathrm{G}^{-699} \rightarrow \mathrm{C}\right)$ in a positive control region of the promoter exhibits an altered frequency in patients with end-stage renal failure (266). A deficit of the C allele was observed among diseased patients and in some etiologic groups (polycystic kidneys, pyelonephritis, and interstitial nephritis) compared with healthy volunteers. This polymorphism may be a marker of prognostic significance for the renal function in diseased individuals. Profound alteration of allele frequencies were found in patients with inflammatory bowel disease such as ulcerative colitis or Crohn's disease in a small case-control study (267). Thus, the B1R promoter gene does not have a specific etiologic influence but rather modifies a downstream inflammatory pathway common to these disorders.

\section{Kinin receptors as pharmacological targets}

Roles for the kallikrein-kinin system in inflammation have been investigated and reviewed extensively (268). As a great number of disease states such as chronic inflammatory pain, edema, asthma, and sepsis have their basis in the inflammatory response, the development of novel antagonist drugs targeted at the B1R and B2R provides a novel therapeutic opportunity. The clinical development of these drugs is at an early stage, with few human clinical studies reported until now and mainly based on peptide compounds $(269-272)$. These charged and rather large molecules may not show the full therapeutic effect of kinin receptor blockade due to limitations in oral bioavailability, distribution, and stability. The potential therapeutic applications of kinin receptor ligands (not always antagonists) include cardiovascular and renal disorders, inflammation, pain, diabetes, asthma, and perhaps cancer.

\subsection{Cardiovascular and renal diseases}

BK is known for its multiple effects on the cardiovascular system and particularly by its vasodilatation and plasma extravasation properties (273), leading to an inflammatory response. Vasodilatation is normally mediated by B2R (274), but under inflammatory conditions, B1R up-regulation mediates kinin-induced vasodilatation and hypotension $(275,276)$. BK-related peptides act as vasodilators through endothelial cells from which secondary mediators are released to affect the vascular smooth muscle. In humans, cardiovascular actions of kinins are mainly correlated to preformed $\mathrm{B} 2 \mathrm{R}$ stimulation (leading to $\mathrm{NO}$ and $\mathrm{PGI}_{2}$ formation) and the contribution of the $\mathrm{B} 1 \mathrm{R}$ is not detectable (130). NO is derived from L-arginine by eNOS. NO diffuses from the endothelium to the smooth muscle where it activates guanylate cyclase. NO-independent ion channels are also suspected to mediate endothelialdependent vasorelaxation. Prostacyclin is also released by kinins from the endothelial cells, probably via the cytosolic $\mathrm{Ca}^{2+}$-sensitive isoforms of $\mathrm{PLA}_{2}$ and stimulates cAMP production in smooth muscle cells (277). These physiological effects of kinins are potentially useful to treat hypertension and ischemic disorders and to maintain renal function (as the kallikrein-kinin system plays a role in handling salt excess).

The local generation of kinins or the inhibition of their degradation and the resulting $\mathrm{B} 2 \mathrm{R}$ stimulation could be of interest to reduce blood pressure or to promote cardioprotective effects $(231,278,279)$.

On the other hand, B1R activation has been shown to exert a protective effect after cardiac ischemia in mice (280). The peptidase-resistant B1R agonist Sar-[D$\mathrm{Phe}^{8}$ ]des-Arg ${ }^{9}-\mathrm{BK}$ has been used to further stimulate 
the formation of compensatory vasculature in a rodent ischemia model after occlusion of the femoral artery (281). FR190997 is a nonpeptide B2R agonist (or partial agonist) derived chemically from a series of B2R antagonists (282). Speculatively, it has been proposed that this drug could be exploited as an antihypertensive or cardioprotective agent, but clinical testing remains to be performed (283). Much experimental and some clinical works on the effect of ACEi naturally suggests that kinin receptor agonists could be used as vasoactive agents, but the inflammatory properties of these compounds probably cannot be dissociated from their vasodilator/angiogenic effects (273). One B2R agonist that has been developed up to a certain point, labradimil (RMP-7), was a peptidase-resistant BK analog used to transiently open the blood-brain barrier, thus deliberately exploiting an inflammatory effect (284).

B1R may not be responsible for the cardiovascular effect of kinins in healthy humans but in the case of tissue injury, the receptor expression is induced, as in the cardiac endothelium of patients with heart failure (285), and B2R expression remains usually unchanged. However infusion of a pharmacologic concentration of the BK agonist des-Arg ${ }^{9}$-BK does not cause vasodilation in the forearm of congestive heart failure patients treated chronically with ACEi.

\subsection{Inflammation}

Injections of substances known to activate the contact system, such as carrageenan, induce a swelling that reaches a maximal response at $3 \mathrm{~h}$ post-injection (286). BK release is related to the intensity of an acute inflammation reaction, based on the inhibitory effect of a B2R antagonist, but repeated injections of the irritant produced a reaction that becomes responsive to a B1R antagonist (Fig. 5). This type of observation was also made using an antigen-induced model of chronic inflammation where the B1R antagonist [Leu $\left.{ }^{8}\right]$ des-Arg ${ }^{9}$-BK was shown to become more potent to inhibit plasma extravasation of joint inflammation as the model progressed (287).

BK administration reproduces two of the cardinal signs of inflammation (rubor, calor) through the activation of $\mathrm{B} 2 \mathrm{R}$ that causes vasodilatation due to NOS and $\mathrm{PLA}_{2}$ stimulation leading to $\mathrm{NO}$ and $\mathrm{PGI}_{2}$ production by vascular endothelial cells. The ensuing exudation of protein-rich fluid from the circulation, facilitated by kinins, is largely determined by the rise of vascular permeability, particularly at the level of postcapillary venules via endothelial cells contraction. This is the essentially vasogenic mechanism of a third cardinal sign of inflammation, swelling (tumor).

Models of chronic inflammation provide the involve-

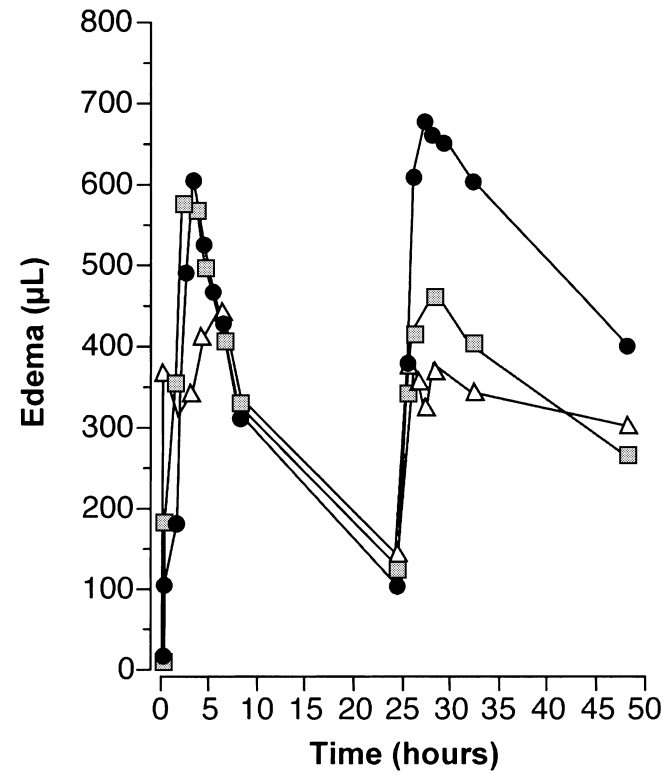

Fig. 5. Effects of kinin receptor antagonists on carrageenaninduced paw edema. Effects of a $\mathrm{B}_{1}$ (Lys[Leu $\left.{ }^{8}\right]$ des-Arg ${ }^{9}-\mathrm{BK}$, $32.5 \mathrm{nmol} / \mathrm{paw}$ ) and $\mathrm{B}_{2}$ (HOE 140, $\left.3.25 \mathrm{nmol} / \mathrm{paw}\right)$ receptor antagonist on carrageenan-induced paw edema. The anti-edema potential of the B1R antagonist is evidenced only at the second challenge, consistent with B1R absence in the uninflamed tissue. Carrageenan was injected twice, at 24-h intervals. Carrageenan $0.5 \%$ (black circle), carrageenan $0.5 \%$ with B1R antagonist (grey square), or with B1R and B2R antagonists (white triangle). (Reproduced with permission from A. Décarie, $\mathrm{PhD}$ Thesis, p. 156, Université de Montréal, 1997)

ment of the B1R (151). The role of infiltrating leukocytes is relevant in these models as they may supply cytokines (IL- $1 \beta$, TNF- $\alpha$ ) levels required to induce B1R expression. Conversely, B1R seems to be of importance in neutrophil accumulation in inflamed tissues, as the ablation of the corresponding gene in mice is associated with a significant defect of this process (mechanism not fully elucidated) (288).

\subsection{Pain and neurological applications}

The specific role of B1R and B2R in inflammatory pain perception (dolor, the 4th cardinal sign of inflammation) is correlated to the amplitude and the kinetics of their expression. B2R are generally constitutively expressed on primary non-myelinated sensory neurons and BK activates these nociceptors to contribute to the acute pain response (289) through the release of DAG (173) and the protein kinase C activation (290).

One of the most promising applications of kinin receptor antagonists is analgesia. A number of animal models of inflammatory pain have been exploited to show that B1R or B2R antagonists exert analgesia (151). Although the interest for a B1R antagonist is currently 
strong, due to their efficacy in the later of persistent phases of inflammatory pain, the analgesic effect of recent nonpeptide antagonists of the $\mathrm{B} 2 \mathrm{R}$ is surprisingly good (LF 16-0687, bradyzide) $(291,292)$. However, the fact that peptide antagonists of either receptor subtype are analgesic may support a peripheral mode of action, as these agents are likely to be excluded from the CNS. A peripheral site of action is further supported by the localized expression of the B1R mRNA in a zymosaninduced inflammatory pain model applied to the rat (291).

On the other hand, the role of the CNS expression of kinin receptors in pain perception is of great interest. The occurrence of "wind up" (facilitation) to repeated dorsal root stimulation in vitro is reduced by about $50 \%$ in the B1R gene knockout mice (288), suggesting the presence of a constitutive B1R population in the pain neurosensory pathways in this species. B1R mRNA is expressed in rat and human dorsal spinal cords (293, 294) and throughout the rostral-caudal portion of monkey brain (295). However, whether the presence of a background mRNA concentration predicts the presence of mature receptors is not clear: there is published evidence showing that the B1R mRNA is detectable in the control rat spinal dorsal cord, but not the corresponding binding sites; however, both increase as a function of the pathology (streptozotocin-induced diabetes) (296).

Abundant preclinical evidence shows that posttraumatic brain edema is reduced by B2R pharmacological blockade $(297,298)$; this is likely to be a vasogenic response. The nonpeptide drug LF 16-0687 is currently being evaluated for this indication in humans. Cultured human brain microvascular endothelial cells express the B1R (299). The biological significance of $\mathrm{B} 1 \mathrm{R}$ activation during inflammation can be considered in the context of both blood-brain barrier permeability and chemoattraction. The activation of $\mathrm{B} 1 \mathrm{R}$ reduces IL-8 secretion by these cells, suggesting dissociation between permeability of fluids and leukocyte trafficking. By this mechanism, activation of B1R would produce a perivascular infiltrate enriched for high molecular weight molecules with a relative paucity of immune cells. Moreover, a correlation has been observed between B1R activity and its expression on peripheral $\mathrm{T}$ lymphocytes in multiple sclerosis patients (300). Nevertheless, B1R activation prevents the infiltration of $\mathrm{T}$ lymphocytes through an artificial blood-brain barrier, suggesting a protective role of B1Rs in this disease via an inhibition of IL-8 secretion.

B2R is widely distributed in the rat brain, but following kindling-induced epilepsy, the relatively low levels of B1R expression, in normal rodents, are functionally detectable in several brain areas (potentiation of electri- cally evoked glutamate overflow) (301).

Local inflammation of viscera, such as small intestine or bladder, and related pain are mediated by endogenous kinins via a viscero-visceral hyper-reflexia. Kinin receptor antagonists were shown to inhibit this hyperreflexia, but a temporal shift of mediation is seen from B2Rs to B1Rs (302). BK-receptor expression in inflammatory bowel disease, namely, ulcerative colitis and Crohn's disease, may be altered in intestinal inflammation. Increased B1R gene and protein expression in active inflammatory bowel disease provides a structural basis for the important role of kinins in chronic inflammation (303).

Clinical trials for the analgesic effects of B1R antagonists are currently being conducted.

\subsection{Diabetes}

Some experimental data suggest that diabetes is another pathological condition that could induce B1R expression. Insulino-dependent diabetes (type I diabetes) derives from an auto-immune response (insulitis) implicating an overproduction of cytokines such as IL$1 \beta$ and TNF- $\alpha$. Moreover, hyperglycemia and oxidative stress can also activate NF- $\kappa \mathrm{B}$. The addition of cytokines overproduction and hyperglycemia could then induce B1R expression through NF- $\kappa \mathrm{B}(304,305)$. The peptide B1R antagonist $\left[\mathrm{Leu}^{8}\right]$ des-Arg ${ }^{9}-\mathrm{BK}$ prevents the progression of steptozotocin-induced insulin-dependent diabetes in rodents (306), but not treatment with Icatibant, suggesting that the B1R has a selective role in the insulitis that precedes diabetes in this model.

Furthermore, established streptozotocin-induced diabetes in rodents is associated with prominent B1R expression $(307,308)$ and the associated hyperalgesia (309). However, these observations were made on insulin-dependent diabetes without insulin treatment, a wasting disease with high blood cytokine levels, and have an uncertain significance for the complications of diabetes in present day human patients. Another line of investigation suggests that kinins exert protective effects in diabetes models in rodents as inhibitors of kininases improved the sensitivity to insulin and as Icatibant significantly reduced the effect of these kininases inhibitors. These observations support that these metabolic effects are mediated by endogenous BK and B2R (310, 311).

\subsection{Renal disease}

Malignant hypertension is observed when B2R knockout mice are overloaded with dietary sodium (312). This confirmed the long time suspected role of the renal kallikrein-kinin system in handling sodium and water metabolism, in parallel to the renin-angio- 
tensin-aldosterone endocrinal axis (313).

Specific polymorphisms of the human kinin receptor locus have been associated with end-stage renal failure (mixed aetiology), hypertension, and nephropathy in diabetics $(259,265,266)$; all these findings are perfectible efforts to link the transmission of this locus to human pathology. The protective effect of kinins in renal disease has been extended to the B1R, as various aspects of the chronic inflammatory response seem to be limited by endogenous ligands of this receptor subtypes in animal models (314).

\subsection{Airway disease}

Icatibant (HOE 140), a widely used peptide B2R antagonist, has been found to significantly improve the ventilatory function in humans with asthma when administered in an aerosol form (269). The mode of action of this drug was not related to an acute bronchodilator action, but rather to a long-term anti-inflammatory effect.

Persistent dry cough is a side effect related to the use of ACEi in a relatively large number of patients. The cause and the mechanism of dry cough is not fully understood but can be attributed to a possible local accumulation of BK that may lead to activation of proinflammatory peptides and a local release of histamine, inducing a cough reflex hypersentivity (264). Another explanation implicates a BK-mediated increase in lung PGs which produce cough and sensitize bronchial contractility $(315,316)$. Several polymorphisms of the human B2R gene may be involved in ACEi-related cough. The genotypic and allelic frequencies of the -58 thymine/cytosine $(-58 \mathrm{~T} / \mathrm{C})$ polymorphism of patients with essential hypertension were analyzed (264). The frequencies of the TT genotype and the $\mathrm{T}$ allele of $-58 \mathrm{~T} / \mathrm{C}$ are higher in the subjects with cough than in subjects without cough. Moreover, $-58 \mathrm{~T}$ was found to have a higher transcription rate than that of $-58 \mathrm{C}$. The higher expression of the B2R might be involved in the occurrence of ACEi-related cough.

\subsection{Angioedema (AE)}

An exon 1 polymorphism in the human B2R gene, in which alleles differ by a $9 \mathrm{bp}$ deletion, appears to confer a higher level of expression, probably due to more stability against the action of RNases. The B2R(-) allele was always present in the most symptomatic cases of HAE in a small series of patients and thus is proposed to modulate in a dominant manner the phenotype of the basic genetic defect of this disorder (130). However, this polymorphism did not predict the incidence of the most common side effect of ACEi, the non-productive cough (260). ACE-induced angioedema is correlated to a decreased ability to degrade des-Arg ${ }^{9}$-BK in hypertensive patients (248). This biological marker has been later attributed to a largely transmissible variability of the expression of membrane APP (250). Encouraging results in the clinical trial of the $\mathrm{B} 2 \mathrm{R}$ antagonist Icatibant support that kinin receptor blockade is of therapeutic interest in HAE (209). It remains to be seen whether B1R blockade could be as or more effective in this and other forms of AE.

\section{Conclusion}

In this review, we tried to show that the complexity of the kallikrein-kinin system results from the interaction of its multiple components. We have exposed both faces of this system, where the ying is often the shadow of the yang. We have also stressed that pathophysiological models and pharmacological approaches validated in animals (potentiation of the cardiovascular effects of kinins, suppression of their proinflammatory effects) are sometimes difficult to apply in humans. Notwithstanding these difficulties, several groups of drugs are now available or being developed in human medicine for the treatment of either the side effects resulting from the chaotic activation of the contact system or the potentiation of the cardioprotective effects of kinins.

Recent experimental works open new pharmacological venues, as is the case for the antiangiogenic property of the heavy chain of HK. It is particularly true for des-Arg'-kinins and their B1R, the molecular target of many novel antagonists. The nonpeptide B1R antagonists are now in development. They look particularly promising in the treatment of inflammatory pain where the roles of the B1R and its agonists have been shown in animals. A number of other applications are awaiting clear clinical conclusions about the applicability of kinin receptor antagonists: inflammation (e.g., inflammatory bowel disease), asthma and allergy, brain edema and wasting states, sepsis, congenital, or drug-induced angioedema.

\section{Acknowledgements}

The laboratory of FM is supported by the Canadian Institutes for Health Research (grant MOP-14077). The laboratory of AA is supported by the Canadian Institutes for Health Research (grant MOP-14077), the Fonds de Recherche en Santé du Québec, and the NIH (grant 1R01-HL079184). The laboratory of NJB is supported by the NIH (grant 1-R01-HL079184). GM received a Fellowship from the Canadian Institutes for Health Research. 
We dedicate this review to Dr. J. Damas, for his retirement. Dr. Damas discovered the Brown Norway rat, the prototype of transgenic animals in kinin research.

\section{References}

1 Abelous J, Bardier E. Les substances hypotensives de l'urine humaine normale. CR Soc Biol. 1909;66:511-512. (in French)

2 Sakamoto W, Satoh F, Gotoh K, Uehara S. Ile-Ser-bradykinin (T-kinin) and Met-Ile-Ser-bradykinin (Met-T-kinin) are released from T-kininogen by an acid proteinase of granulomatous tissues in rats. FEBS Lett. 1987;219:437-440.

3 Takagaki Y, Kitamura N, Nakanishi S. Cloning and sequence analysis of cDNAs for human high molecular weight and low molecular weight prekininogens. Primary structures of two human prekininogens. J Biol Chem. 1985;260:8601-8609.

4 Kitamura N, Kitagawa H, Fukushima D, Takagaki Y, Miyata T, Nakanishi S. Structural organization of the human kininogen gene and a model for its evolution. J Biol Chem. 1985;260: $8610-8617$.

5 Adam A, Albert A, Calay G, Closset J, Damas J, Franchimont P. Human kininogens of low and high molecular mass: quantification by radioimmunoassay and determination of reference values. Clin Chem. 1985;31:423-426.

6 Higashiyama S, Ohkubo I, Ishiguro H, Sasaki M, Matsuda T, Nakamura R. Heavy chain of human high molecular weight and low molecular weight kininogens binds calcium ion. Biochemistry. 1987;26:7450-7458.

7 Salvesen G, Parkes C, Abrahamson M, Grubb A, Barrett AJ. Human low-Mr kininogen contains three copies of a cystatin sequence that are divergent in structure and in inhibitory activity for cysteine proteinases. Biochem J. 1986;234:429-434.

8 Jiang YP, Muller-Esterl W, Schmaier AH. Domain 3 of kininogens contains a cell-binding site and a site that modifies thrombin activation of platelets. J Biol Chem. 1992;267:37123717.

9 Hasan AA, Cines DB, Ngaiza JR, Jaffe EA, Schmaier AH. Highmolecular-weight kininogen is exclusively membrane bound on endothelial cells to influence activation of vascular endothelium. Blood. 1995;85:3134-3143.

10 Colman RW, Jameson BA, Lin Y, Johnson D, Mousa SA. Domain 5 of high molecular weight kininogen (kininostatin) down-regulates endothelial cell proliferation and migration and inhibits angiogenesis. Blood. 2000;95:543-550.

11 Lin Y, Pixley RA, Colman RW. Kinetic analysis of the role of zinc in the interaction of domain 5 of high-molecular weight kininogen (HK) with heparin. Biochemistry. 2000;39:51045110.

12 Tait JF, Fujikawa K. Primary structure requirements for the binding of human high molecular weight kininogen to plasma prekallikrein and factor XI. J Biol Chem. 1987;262:1165111656.

13 Silverberg M, Nicoll JE, Kaplan AP. The mechanism by which the light chain of cleaved HMW-kininogen augments the activation of prekallikrein, factor XI and Hageman factor. Thromb Res. 1980;20:173-189.

14 Muller-Esterl W, Vohle-Timmermann M, Boos B, Dittman B. Purification and properties of human low molecular weight kininogen. Biochim Biophys Acta. 1982;706:145-152.

15 Beaubien G, Rosinski-Chupin I, Mattei MG, Mbikay M,
Chretien M, Seidah NG. Gene structure and chromosomal localization of plasma kallikrein. Biochemistry. 1991;30:1628-1635.

16 Mandle RJ, Colman RW, Kaplan AP. Identification of prekallikrein and high-molecular-weight kininogen as a complex in human plasma. Proc Natl Acad Sci U S A. 1976;73:4179-4183.

17 Bhoola KD, Figueroa CD, Worthy K. Bioregulation of kinins: kallikreins, kininogens, and kininases. Pharmacol Rev. 1992;44: $1-80$.

18 Reddigari S, Kaplan AP. Quantification of human high molecular weight kininogen by immunoblotting with a monoclonal anti-light chain antibody. J Immunol Methods. 1989;119:19-25.

19 Kaplan AP, Joseph K, Shibayama Y, Reddigari S, Ghebrehiwet $\mathrm{B}$, Silverberg M. The intrinsic coagulation/kinin-forming cascade: assembly in plasma and cell surfaces in inflammation. Adv Immunol. 1997;66:225-272.

20 Merlini PA, Cugno M, Rossi ML, et al. Activation of the contact system and inflammation after thrombolytic therapy in patients with acute myocardial infarction. Am J Cardiol. 2004;93:822825.

21 Kaplan AP, Joseph K, Silverberg M. Pathways for bradykinin formation and inflammatory disease. J Allergy Clin Immunol. 2002;109:195-209.

22 Kaplan AP, Silverberg M. The coagulation-kinin pathway of human plasma. Blood. 1987;70:1-15.

23 Mori K, Sakamoto W, Nagasawa S. Studies on human high molecular weight (HMW) kininogen. III. Cleavage of HMW kininogen by the action of human salivary kallikrein. J Biochem (Tokyo). 1981;90:503-509.

24 Guo YL, Colman RW. Two faces of high-molecular-weight kininogen (HK) in angiogenesis: bradykinin turns it on and cleaved HK (HKa) turns it off. J Thromb Haemost. 2005;3:670676.

25 Zhao Y, Qiu Q, Mahdi F, Shariat-Madar Z, Rojkjaer R, Schmaier AH. Assembly and activation of HK-PK complex on endothelial cells results in bradykinin liberation and NO formation. Am J Physiol Heart Circ Physiol. 2001;280:H1821-1829.

26 Schmaier AH, Kuo A, Lundberg D, Murray S, Cines DB. The expression of high molecular weight kininogen on human umbilical vein endothelial cells. J Biol Chem. 1988;263:1632716333.

27 van Iwaarden F, de Groot PG, Bouma BN. The binding of high molecular weight kininogen to cultured human endothelial cells. J Biol Chem. 1988;263:4698-4703.

28 Reddigari SR, Kuna P, Miragliotta G, Shibayama Y, Nishikawa K, Kaplan AP. Human high molecular weight kininogen binds to human umbilical vein endothelial cells via its heavy and light chains. Blood. 1993;81:1306-1311.

29 Hasan AA, Cines DB, Herwald H, Schmaier AH, Muller-Esterl W. Mapping the cell binding site on high molecular weight kininogen domain 5. J Biol Chem. 1995;270:19256-19261.

30 Herwald H, Hasan AA, Godovac-Zimmermann J, Schmaier AH, Muller-Esterl W. Identification of an endothelial cell binding site on kininogen domain D3. J Biol Chem. 1995;270:14634-14642.

31 Motta G, Rojkjaer R, Hasan AA, Cines DB, Schmaier AH. High molecular weight kininogen regulates prekallikrein assembly and activation on endothelial cells: a novel mechanism for contact activation. Blood. 1998;91:516-528.

32 Nishikawa K, Shibayama Y, Kuna P, Calcaterra E, Kaplan AP, Reddigari SR. Generation of vasoactive peptide bradykinin from human umbilical vein endothelium-bound high molecular weight kininogen by plasma kallikrein. Blood. 1992;80:1980 
1988.

33 Hasan AA, Zisman T, Schmaier AH. Identification of cytokeratin 1 as a binding protein and presentation receptor for kininogens on endothelial cells. Proc Natl Acad Sci U S A. 1998;95:3615-3620.

34 Shariat-Madar Z, Mahdi F, Schmaier AH. Mapping binding domains of kininogens on endothelial cell cytokeratin 1. J Biol Chem. 1999;274:7137-7145.

35 Herwald H, Dedio J, Kellner R, Loos M, Muller-Esterl W. Isolation and characterization of the kininogen-binding protein p33 from endothelial cells. Identity with the $\mathrm{gClq}$ receptor. J Biol Chem. 1996;271:13040-13047.

36 Joseph K, Ghebrehiwet B, Peerschke EI, Reid KB, Kaplan AP. Identification of the zinc-dependent endothelial cell binding protein for high molecular weight kininogen and factor XII: identity with the receptor that binds to the globular "heads" of Clq (gClq-R). Proc Natl Acad Sci U S A. 1996;93:8552-8557.

37 Colman RW, Pixley RA, Najamunnisa S, Yan W, Wang J, Mazar A, et al. Binding of high molecular weight kininogen to human endothelial cells is mediated via a site within domains 2 and 3 of the urokinase receptor. J Clin Invest. 1997;100:14811487.

38 Schmaier AH. Plasma kallikrein/kinin system: a revised hypothesis for its activation and its physiologic contributions. Curr Opin Hematol. 2000;7:261-265.

39 Mahdi F, Shariat-Madar Z, Todd RF, 3rd, Figueroa CD, Schmaier AH. Expression and colocalization of cytokeratin 1 and urokinase plasminogen activator receptor on endothelial cells. Blood. 2001;97:2342-2350.

40 Mahdi F, Madar ZS, Figueroa CD, Schmaier AH. Factor XII interacts with the multiprotein assembly of urokinase plasminogen activator receptor, $\mathrm{gClqR}$, and cytokeratin 1 on endothelial cell membranes. Blood. 2002;99:3585-3596.

41 Clements J, Hooper J, Dong Y, Harvey T. The expanded human kallikrein (KLK) gene family: genomic organisation, tissuespecific expression and potential functions. Biol Chem. 2001; 382:5-14.

42 Mahabeer R, Bhoola KD. Kallikrein and kinin receptor genes. Pharmacol Ther. 2000;88:77-89.

43 Marcondes S, Antunes E. The plasma and tissue kininogenkallikrein-kinin system: role in the cardiovascular system. Curr Med Chem Cardiovasc Hematol Agents. 2005;3:33-44.

44 Kaplan AP, Joseph K, Shibayama Y, Nakazawa Y, Ghebrehiwet $\mathrm{B}$, Reddigari $\mathrm{S}$, et al. Bradykinin formation. Plasma and tissue pathways and cellular interactions. Clin Rev Allergy Immunol. 1998;16:403-429.

45 Fogaca SE, Melo RL, Pimenta DC, Hosoi K, Juliano L, Juliano MA. Differences in substrate and inhibitor sequence specificity of human, mouse and rat tissue kallikreins. Biochem J. 2004;380:775-781.

46 Dobrovolsky AB, Titaeva EV. The fibrinolysis system: regulation of activity and physiologic functions of its main components. Biochemistry (Mosc). 2002;67:99-108.

47 Molinaro G, Gervais N, Adam A. Biochemical basis of angioedema associated with recombinant tissue plasminogen activator treatment: an in vitro experimental approach. Stroke. 2002;33:1712-1716.

48 Norris LA. Blood coagulation. Best Pract Res Clin Obstet Gynaecol. 2003;17:369-383.

49 Breen P. Basics of coagulation pathways. Int Anesthesiol Clin. 2004;42:1-9.
50 Pixley RA, Schapira M, Colman RW. The regulation of human factor XIIa by plasma proteinase inhibitors. J Biol Chem. 1985;260:1723-1729.

51 Cugno M, Hack CE, de Boer JP, Eerenberg AJ, Agostoni A, Cicardi M. Generation of plasmin during acute attacks of hereditary angioedema. J Lab Clin Med. 1993;121:38-43.

52 Chai KX, Chen VC, Ni A, Lindpainther K, Rubattu S, Chao L, et al. Molecular cloning and expression of rat kallistatin gene. Biochim Biophys Acta. 1997;1353:277-286.

53 Chao J, Miao RQ, Chen V, Chen LM, Chao L. Novel roles of kallistatin, a specific tissue kallikrein inhibitor, in vascular remodeling. Biol Chem. 2001;382:15-21.

54 Emeis JJ, Kooistra T. Interleukin 1 and lipopolysaccharide induce an inhibitor of tissue-type plasminogen activator in vivo and in cultured endothelial cells. J Exp Med. 1986;163:1260 1266.

55 Erdös E, Skidgel R. Metabolism of bradykinin by peptidases in health and disease. In: Farmer S, ed. The kinin system. San Diego: Academic Press; 1997. p. 111-141.

56 Turner AJ, Hooper NM. The angiotensin-converting enzyme gene family: genomics and pharmacology. Trends Pharmacol Sci. 2002;23:177-183.

57 Hagaman JR, Moyer JS, Bachman ES, Sibony M, Magyar PL, Welch JE, et al. Angiotensin-converting enzyme and male fertility. Proc Natl Acad Sci U S A. 1998;95:2552-2557.

58 Georgiadis D, Beau F, Czarny B, Cotton J, Yiotakis A, Dive V. Roles of the two active sites of somatic angiotensin-converting enzyme in the cleavage of angiotensin I and bradykinin: insights from selective inhibitors. Circ Res. 2003;93:148-154.

59 Soubrier F, Alhenc-Gelas F, Hubert C, Allegrini J, John M, Tregear G, et al. Two putative active centers in human angiotensin I-converting enzyme revealed by molecular cloning. Proc Natl Acad Sci U S A. 1988;85:9386-9390.

60 Andujar-Sanchez M, Camara-Artigas A, Jara-Perez V. A calorimetric study of the binding of lisinopril, enalaprilat and captopril to angiotensin-converting enzyme. Biophys Chem. 2004;111:183-189.

61 Hooper NM, Turner AJ. An ACE structure. Nat Struct Biol. 2003;10:155-157.

62 Ehlers MR, Fox EA, Strydom DJ, Riordan JF. Molecular cloning of human testicular angiotensin-converting enzyme: the testis isozyme is identical to the C-terminal half of endothelial angiotensin-converting enzyme. Proc Natl Acad Sci U S A. 1989;86:7741-7745.

63 Oppong SY, Hooper NM. Characterization of a secretase activity which releases angiotensin-converting enzyme from the membrane. Biochem J. 1993;292:597-603.

64 Allinson TM, Parkin ET, Condon TP, Schwager SL, Sturrock ED, Turner AJ, et al. The role of ADAM10 and ADAM17 in the ectodomain shedding of angiotensin converting enzyme and the amyloid precursor protein. Eur J Biochem. 2004;271:25392547.

65 Parkin ET, Trew A, Christie G, Faller A, Mayer R, Turner AJ, et al. Structure-activity relationship of hydroxamate-based inhibitors on the secretases that cleave the amyloid precursor protein, angiotensin converting enzyme, CD23, and pro-tumor necrosis factor-alpha. Biochemistry. 2002;41:4972-4981.

66 Igic R, Behnia R. Properties and distribution of angiotensin I converting enzyme. Curr Pharm Des. 2003;9:697-706.

67 Donoghue M, Hsieh F, Baronas E, Godbout K, Gosselin M, Staglinano $\mathrm{N}$, et al. A novel angiotensin-converting enzyme- 
related carboxypeptidase (ACE2) converts angiotensin I to angiotensin 1-9. Circ Res. 2000;87:E1-E9.

68 Vickers C, Hales P, Kaushik V, Dick L, Gavin J, Tang J, et al. Hydrolysis of biological peptides by human angiotensinconverting enzyme-related carboxypeptidase (ACE2). J Biol Chem. 2002;28:28.

69 Tian XL, Pinto YM, Costerousse O, Franz WM, Lippolat A, Hoffman S, et al. Over-expression of angiotensin converting enzyme- 1 augments cardiac hypertrophy in transgenic rats. Hum Mol Genet. 2004;13:1441-1450.

70 Itoyama S, Keicho N, Quy T, Phi NC, Long HT, Ha le D, et al. ACE1 polymorphism and progression of SARS. Biochem Biophys Res Commun. 2004;323:1124-1129.

71 Hubert C, Houot AM, Corvol P, Soubrier F. Structure of the angiotensin I-converting enzyme gene. Two alternate promoters correspond to evolutionary steps of a duplicated gene. J Biol Chem. 1991;266:15377-15383.

72 Blais C Jr, Marceau F, Rouleau JL, Adam A. The kallikreinkininogen-kinin system: lessons from the quantification of endogenous kinins. Peptides. 2000;21:1903-1940.

73 Erdos EG. Some old and some new ideas on kinin metabolism. J Cardiovasc Pharmacol. 1990;15:S20-S24.

74 Inokuchi J, Nagamatsu A. Tripeptidyl carboxypeptidase activity of kininase II (angiotensin-converting enzyme). Biochim Biophys Acta. 1981;662:300-307.

75 Oshima G, Hiraga Y, Shirono K, Oh-ishi S, Sakakibara S, Kinoshita T. Cleavage of des-Arg9-bradykinin by angiotensin Iconverting enzyme from pig kidney cortex. Experientia. 1985; 41:325-328.

76 Kondoh G, Tojo H, Nakatani Y, Komazawa N, Murata C, Yamagata $\mathrm{K}$, et al. Angiotensin-converting enzyme is a GPIanchored protein releasing factor crucial for fertilization. Nat Med. 2005;11:160-166.

77 Tsujioka H, Misumi Y, Takami N, Ikehara Y. Posttranslational modification of glycosylphosphatidylinositol (GPI)-specific phospholipase D and its activity in cleavage of GPI anchors. Biochem Biophys Res Commun. 1998;251:737-743.

78 Kohlstedt K, Shoghi F, Muller-Esterl W, Busse R, Fleming I. CK2 phosphorylates the angiotensin-converting enzyme and regulates its retention in the endothelial cell plasma membrane. Circ Res. 2002;91:749-756

79 Kohlstedt K, Brandes RP, Muller-Esterl W, Busse R, Fleming I. Angiotensin-converting enzyme is involved in outside-in signaling in endothelial cells. Circ Res. 2004;94:60-67.

80 Rigat B, Hubert C, Alhenc-Gelas F, Cambien F, Corvol P, Soubrier F. An insertion/deletion polymorphism in the angiotensin I-converting enzyme gene accounting for half the variance of serum enzyme levels. J Clin Invest. 1990;86:1343-1346.

81 Danser AH, Schunkert H. Renin-angiotensin system gene polymorphisms: potential mechanisms for their association with cardiovascular diseases. Eur J Pharmacol. 2000;410:303-316.

82 Brown NJ, Blais C Jr, Gandhi SK, Adam A. ACE insertion /deletion genotype affects bradykinin metabolism. J Cardiovasc Pharmacol. 1998;32:373-377.

83 Mattu RK, Needham EW, Galton DJ, Frangos E, Clark AJ, Caulfield M. A DNA variant at the angiotensin-converting enzyme gene locus associates with coronary artery disease in the Caerphilly Heart Study. Circulation. 1995;91:270-274.

84 Cambien F, Poirier O, Lecerf L, Evans A, Cambou JP, Arveiler $\mathrm{D}$, et al. Deletion polymorphism in the gene for angiotensinconverting enzyme is a potent risk factor for myocardial infarc- tion. Nature. 1992;359:641-644.

85 Kolsch H, Jessen F, Freymann N, Kreis M, Hentschel F, Maier W, et al. ACE I/D polymorphism is a risk factor of Alzheimer's disease but not of vascular dementia. Neurosci Lett. 2005; 377:37-39.

86 Schunkert H, Hense HW, Holmer SR, Stender M, Perz S, Keil $\mathrm{U}$, et al. Association between a deletion polymorphism of the angiotensin-converting-enzyme gene and left ventricular hypertrophy. N Engl J Med. 1994;330:1634-1638.

87 Marre M, Jeunemaitre X, Gallois Y, Rodier M, Chatellier G, Sert C, et al. Contribution of genetic polymorphism in the reninangiotensin system to the development of renal complications in insulin-dependent diabetes: Genetique de la Nephropathie Diabetique (GENEDIAB) study group. J Clin Invest. 1997;99: $1585-1595$.

88 Hooper NM. Families of zinc metalloproteases. FEBS Lett. 1994;354:1-6.

89 Turner AJ, Isaac RE, Coates D. The neprilysin (NEP) family of zinc metalloendopeptidases: genomics and function. Bioessays. 2001;23:261-269.

90 Turner AJ, Tanzawa K. Mammalian membrane metallopeptidases: NEP, ECE, KELL, and PEX. Faseb J. 1997;11:355-364.

91 Bonvouloir N, Lemieux N, Crine P, Boileau G, DesGroseillers L. Molecular cloning, tissue distribution, and chromosomal localization of MMEL2, a gene coding for a novel human member of the neutral endopeptidase-24.11 family. DNA Cell Biol. 2001;20:493-498.

92 Barker PE, Shipp MA, D’Adamio L, Masteller EL, Reinherz EL. The common acute lymphoblastic leukemia antigen gene maps to chromosomal region 3 (q21-q27). J Immunol. 1989;142: 283-287.

93 Kerr MA, Kenny AJ. The purification and specificity of a neutral endopeptidase from rabbit kidney brush border. Biochem J. 1974;137:477-488.

94 Gafford JT, Skidgel RA, Erdos EG, Hersh LB. Human kidney "enkephalinase", a neutral metalloendopeptidase that cleaves active peptides. Biochemistry. 1983;22:3265-3271.

95 Decarie A, Raymond P, Gervais N, Couture R, Adam A. Serum interspecies differences in metabolic pathways of bradykinin and [des-Arg9]BK: influence of enalaprilat. Am J Physiol. 1996;271: H1340-H1347.

96 Iwata N, Tsubuki S, Takaki Y, Watanabe K, Sekiguchi M, Hosoki E, et al. Identification of the major Abeta1-42-degrading catabolic pathway in brain parenchyma: suppression leads to biochemical and pathological deposition. Nat Med. 2000;6:143150.

97 Kanazawa M, Casley DJ, Sybertz EJ, Haslanger MF, Johnston CI. Localization and characterization of neutral metalloendopeptidase (EC 3.4.24.11), the degradative enzyme for atrial natriuretic peptide, in rat kidney using a radioiodinated neutral metalloendopeptidase inhibitor. J Pharmacol Exp Ther. 1992; 261:1231-1237.

98 Rawlings ND, Barrett AJ. MEROPS: the peptidase database. Nucleic Acids Res. 2000;28:323-325.

99 Cottrell GS, Hooper NM, Turner AJ. Cloning, expression, and characterization of human cytosolic aminopeptidase P: a single manganese (II)-dependent enzyme. Biochemistry. 2000;39: 15121-15128.

100 Venema RC, Ju H, Zou R, Venema VJ, Ryan JW. Cloning and tissue distribution of human membrane-bound aminopeptidase P. Biochim Biophys Acta. 1997;1354:45-48. 
101 Molinaro G, Carmona AK, Juliano MA, Juliano L, Malitsukaya E, Yessine MA, et al. Human recombinant membrane-bound aminopeptidase P: production of a soluble form and characterization using novel, internally quenched fluorescent substrates. Biochem J. 2005;385:389-397.

102 Molinaro G, Boileau G, Adam A. Aminopeptidase P and vasoactive peptides: from fundamental aspects to clinical interests. In: Hooper NM, Lendeckel U, eds. Aminopeptidases in biology and disease. London: Kluwer Academic/Plenum Publishers; 2004. p. 251-269.

103 Hooper NM, Hryszko J, Oppong SY, Turner AJ. Inhibition by converting enzyme inhibitors of pig kidney aminopeptidase P. Hypertension. 1992;19:281-285.

104 Ersahin C, Szpaderska AM, Orawski AT, Simmons WH. Aminopeptidase $\mathrm{P}$ isozyme expression in human tissues and peripheral blood mononuclear cell fractions. Arch Biochem Biophys. 2005;435:303-310.

105 Sprinkle TJ, Caldwell C, Ryan JW. Cloning, chromosomal sublocalization of the human soluble aminopeptidase $\mathrm{P}$ gene (XPNPEP1) to 10q25.3 and conservation of the putative proton shuttle and metal ligand binding sites with XPNPEP2. Arch Biochem Biophys. 2000;378:51-56.

106 Sprinkle TJ, Stone AA, Venema RC, Denslow ND, Caldwell C, Ryan JW. Assignment of the membrane-bound human aminopeptidase P gene (XPNPEP2) to chromosome Xq25. Genomics. 1998;50:114-116.

107 Hooper NM, Turner AJ. Ectoenzymes of the kidney microvillar membrane. Aminopeptidase P is anchored by a glycosyl-phosphatidylinositol moiety. FEBS Lett. 1988;229:340-344.

108 Ryan JW, Berryer P, Chung AY, Sheffy DH. Characterization of rat pulmonary vascular aminopeptidase $\mathrm{P}$ in vivo: role in the inactivation of bradykinin. J Pharmacol Exp Ther. 1994;269: 941-947.

109 Prechel MM, Orawski AT, Maggiora LL, Simmons WH. Effect of a new aminopeptidase $\mathrm{P}$ inhibitor, apstatin, on bradykinin degradation in the rat lung. J Pharmacol Exp Ther. 1995;275: 1136-1142.

110 Ersahin C, Simmons WH. Inhibition of both aminopeptidase P and angiotensin-converting enzyme prevents bradykinin degradation in the rat coronary circulation. J Cardiovasc Pharmacol. 1997;30:96-101.

111 Ryan JW, Papapetropoulos A, Ju H, Denslow ND, Antonov A, Virmani R, et al. Aminopeptidase $\mathrm{P}$ is disposed on human endothelial cells. Immunopharmacology. 1996;32:149-152.

112 Lasch J, Moschner S, Sann H, Zellmer S, Koelsch R. Aminopeptidase $\mathrm{P}-$ a cell-surface antigen of endothelial and lymphoid cells: catalytic and immuno-histotopical evidences. Biol Chem. 1998;379:705-709

113 Harbeck HT, Mentlein R. Aminopeptidase P from rat brain. Purification and action on bioactive peptides. Eur $\mathrm{J}$ Biochem. 1991;198:451-458.

114 Rusu I, Yaron A. Aminopeptidase P from human leukocytes. Eur J Biochem. 1992;210:93-100.

115 Gilmartin L, O’Cuinn G. Dipeptidyl aminopeptidase IV and aminopeptidase $\mathrm{P}$, two proline specific enzymes from the cytoplasm of guinea-pig brain: their role in metabolism of peptides containing consecutive prolines. Neurosci Res. 1999;34:1-11.

116 Simmons WH, Orawski AT. Membrane-bound aminopeptidase $\mathrm{P}$ from bovine lung. Its purification, properties, and degradation of bradykinin. J Biol Chem. 1992;267:4897-4903.

117 Orawski AT, Simmons WH. Purification and properties of membrane-bound aminopeptidase $\mathrm{P}$ from rat lung. Biochemistry. 1995;34:11227-11236.

118 Yoshimoto T, Orawski AT, Simmons WH. Substrate specificity of aminopeptidase $\mathrm{P}$ from Escherichia coli: comparison with membrane-bound forms from rat and bovine lung. Arch Biochem Biophys. 1994;311:28-34.

119 Blais C Jr, Marc-Aurele J, Simmons WH, Loute G, Thibault P, Skidgel RA, et al. Des-Arg9-bradykinin metabolism in patients who presented hypersensitivity reactions during hemodialysis: role of serum ACE and aminopeptidase P. Peptides. 1999;20: 421-430.

120 Tan F, Chan SJ, Steiner DF, Schilling JW, Skidgel RA. Molecular cloning and sequencing of the cDNA for human membrane-bound carboxypeptidase $\mathrm{M}$. Comparison with carboxypeptidases A, B, H, and N. J Biol Chem. 1989;264:1316513170.

121 Skidgel RA. Basic carboxypeptidases: regulators of peptide hormone activity. Trends Pharmacol Sci. 1988;9:299-304.

122 Lambeir AM, Durinx C, Scharpe S, De Meester I. Dipeptidylpeptidase IV from bench to bedside: an update on structural properties, functions, and clinical aspects of the enzyme DPP IV. Crit Rev Clin Lab Sci. 2003;40:209-294.

123 Mentlein R. Dipeptidyl-peptidase IV (CD26) - role in the inactivation of regulatory peptides. Regul Pept. 1999;85:9-24.

124 Olsen J, Kokholm K, Noren O, Sjostrom H. Structure and expression of aminopeptidase N. Adv Exp Med Biol. 1997;421: 47-57.

125 Hoffmann T, Faust J, Neubert K, Ansorge S. Dipeptidyl peptidase IV (CD 26) and aminopeptidase N (CD 13) catalyzed hydrolysis of cytokines and peptides with N-terminal cytokine sequences. FEBS Lett. 1993;336:61-64.

126 Ward PE, Benter IF, Dick L, Wilk S. Metabolism of vasoactive peptides by plasma and purified renal aminopeptidase $\mathrm{M}$. Biochem Pharmacol. 1990;40:1725-1732.

127 Pelorosso FG, Brodsky PT, Zold CL, Rothlin RP. Potentiation of des-Arg9-kallidin induced vasoconstrictor responses by metallopeptidase inhibition in isolated human umbilical artery. J Pharmacol Exp Ther. 2005;313:1355-1360.

128 Drapeau G, deBlois D, Marceau F. Hypotensive effects of Lysdes-Arg9-bradykinin and metabolically protected agonists of B1 receptors for kinins. J Pharmacol Exp Ther. 1991;259:997-1003.

129 Leeb-Lundberg LM, Marceau F, Muller-Esterl W, Pettibone DJ, Zuraw BL. International union of pharmacology. XLV. Classification of the kinin receptor family: from molecular mechanisms to pathophysiological consequences. Pharmacol Rev. 2005;57: 27-77.

130 Marceau F, Hess JF, Bachvarov DR. The B1 receptors for kinins. Pharmacol Rev. 1998;50:357-386.

131 Babiuk C, Marceau F, St-Pierre S, Regoli D. Kininases and vascular responses to kinins. Eur J Pharmacol. 1982;78:167-174.

132 Regoli D, Barabe J, Park WK. Receptors for bradykinin in rabbit aortae. Can J Physiol Pharmacol. 1977;55:855-867.

133 Vavrek RJ, Stewart JM. Competitive antagonists of bradykinin. Peptides. 1985;6:161-164.

134 Hock FJ, Wirth K, Albus U, Linz W, Gerhards HJ, Wiemer G, et al. Hoe 140 a new potent and long acting bradykinin-antagonist: in vitro studies. Br J Pharmacol. 1991;102:769-773.

135 Houle S, Larrivee JF, Bachvarova M, Bouthillier J, Bachvarov DR, Marceau F. Antagonist-induced intracellular sequestration of rabbit bradykinin $\mathrm{B}(2)$ receptor. Hypertension. 2000;35: 1319-1325. 
136 Regoli D, Nsa Allogho S, Rizzi A, Gobeil FJ. Bradykinin receptors and their antagonists. Eur J Pharmacol. 1998;348:1-10.

137 Salvino JM, Seoane PR, Douty BD, Awad MM, Dolle RE, Houck WT, et al. Design of potent non-peptide competitive antagonists of the human bradykinin B2 receptor. J Med Chem. 1993;36:2583-2584.

138 Altamura M, Meini S, Quartara L, Maggi CA. Nonpeptide antagonists for kinin receptors. Regul Pept. 1999;80:13-26.

139 Horlick RA, Ohlmeyer MH, Stroke IL, Strohl B, Pan G, Schilling AE, et al. Small molecule antagonists of the bradykinin B1 receptor. Immunopharmacology. 1999;43:169-177.

140 Wood MR, Kim JJ, Han W, Dorsey BD, Homnick CF, DiPardo $\mathrm{RM}$, et al. Benzodiazepines as potent and selective bradykinin B1 antagonists. J Med Chem. 2003;46:1803-1806.

141 Morissette G, Fortin JP, Otis S, Bouthillier J, Marceau F. A novel nonpeptide antagonist of the kinin B1 receptor: effects at the rabbit receptor. J Pharmacol Exp Ther. 2004;311:1121-1130.

142 Ritchie TJ, Dziadulewicz EK, Culshaw AJ, Muller W, Burgess GM, Bloomfield GC, et al. Potent and orally bioavailable nonpeptide antagonists at the human bradykinin $\mathrm{B}(1)$ receptor based on a 2-alkylamino-5-sulfamoylbenzamide core. J Med Chem. 2004; 47:4642-4644.

143 Gougat J, Ferrari B, Sarran L, Planchenault C, Poncelet M, Maruani J, et al. SSR240612[(2R)-2-[((3R)-3-(1,3-benzodioxol5-yl)-3-[[(6-methoxy-2-naphthyl)sulfonyl ] amino] propanoyl) amino]-3-(4-[[2R,6S)-2,6-dimethylpiperidinyl]methyl]phenyl)$\mathrm{N}$-isopropyl-N-methylpropanamide hydrochloride], a new nonpeptide antagonist of the bradykinin B1 receptor: biochemical and pharmacological characterization. J Pharmacol Exp Ther. 2004;309:661-669.

144 Ma D, Xia C, Jiang J, Zhang J. First total synthesis of martinellic acid, a naturally occurring bradykinin receptor antagonist. Org Lett. 2001;3:2189-2191.

145 McEachern AE, Shelton ER, Bhakta S, Obernolte R, Bach C, Zuppan $\mathrm{P}$, et al. Expression cloning of a rat $\mathrm{B} 2$ bradykinin receptor. Proc Natl Acad Sci U S A. 1991;88:7724-7728.

146 Menke JG, Borkowski JA, Bierilo KK, MacNeil T, Derrick AW, Schneck KA, et al. Expression cloning of a human B1 bradykinin receptor. J Biol Chem. 1994;269:21583-21586.

147 Bachvarov DR, Hess JF, Menke JG, Larrivee JF, Marceau F. Structure and genomic organization of the human B1 receptor gene for kinins (BDKRB1). Genomics. 1996;33:374-381.

148 Yang X, Polgar P. Genomic structure of the human bradykinin $\mathrm{B} 1$ receptor gene and preliminary characterization of its regulatory regions. Biochem Biophys Res Commun. 1996;222:718725.

149 Leeb-Lundberg LM, Mathis SA, Herzig MC. Antagonists of bradykinin that stabilize a G-protein-uncoupled state of the B2 receptor act as inverse agonists in rat myometrial cells. J Biol Chem. 1994;269:25970-25973.

150 Fredriksson R, Lagerstrom MC, Lundin LG, Schioth HB. The Gprotein-coupled receptors in the human genome form five main families. Phylogenetic analysis, paralogon groups, and fingerprints. Mol Pharmacol. 2003;63:1256-1272.

151 Couture R, Harrisson M, Vianna RM, Cloutier F. Kinin receptors in pain and inflammation. Eur J Pharmacol. 2001; 429:161-176.

152 Kammerer S, Braun A, Arnold N, Roscher AA. The human bradykinin B2 receptor gene: full length cDNA, genomic organization and identification of the regulatory region. Biochem Biophys Res Commun. 1995;211:226-233.
153 Cayla C, Merino VF, Cabrini DA, Silva JA Jr, Pesquero JB, Bader M. Structure of the mammalian kinin receptor gene locus. Int Immunopharmacol. 2002;2:1721-1727.

154 Tschope C, Heringer-Walther S, Koch M, Spillmann F, Wandorf $\mathrm{M}$, Leitner E, et al. Upregulation of bradykinin B1-receptor expression after myocardial infarction. Br J Pharmacol. 2000; 129:1537-1538.

155 Phagoo SB, Yaqoob M, McIntyre P, Jones C, Burgess GM. Cytokines increase $\mathrm{B} 1$ bradykinin receptor mRNA and protein levels in human lung fibroblasts. Biochem Soc Trans. 1997; 25:43S.

156 Zhou X, Polgar P, Taylor L. Roles for interleukin-1beta, phorbol ester and a post-transcriptional regulator in the control of bradykinin B1 receptor gene expression. Biochem J. 1998;330:361366.

157 Phagoo SB, Yaqoob M, Herrera-Martinez E, McIntyre P, Jones $\mathrm{C}$, Burgess GM. Regulation of bradykinin receptor gene expression in human lung fibroblasts. Eur J Pharmacol. 2000;397:237246.

158 Davis AJ, Perkins MN. Induction of B1 receptors in vivo in a model of persistent inflammatory mechanical hyperalgesia in the rat. Neuropharmacology. 1994;33:127-133.

159 Larrivee JF, Bachvarov DR, Houle F, Landry J, Huot J, Marceau F. Role of the mitogen-activated protein kinases in the expression of the kinin B1 receptors induced by tissue injury. J Immunol. 1998;160:1419-1426.

160 Campos MM, Souza GE, Calixto JB. In vivo B1 kinin-receptor upregulation Evidence for involvement of protein kinases and nuclear factor kappaB pathways. Br J Pharmacol. 1999;127: 1851-1859.

161 Ganju P, Davis A, Patel S, Nunez X, Fox A. p38 stress-activated protein kinase inhibitor reverses bradykinin $\mathrm{B}(1)$ receptormediated component of inflammatory hyperalgesia. Eur J Pharmacol. 2001;421:191-199.

162 Medeiros R, Cabrini DA, Ferreira J, Fernandes ES, Mori MA, Pesquero JB, et al. Bradykinin B1 receptor expression induced by tissue damage in the rat portal vein: a critical role for mitogen-activated protein kinase and nuclear factor-kappaB signaling pathways. Circ Res. 2004;94:1375-1382.

163 Sabourin T, Morissette G, Bouthillier J, Levesque L, Marceau F. Expression of kinin $\mathrm{B}(1)$ receptor in fresh or cultured rabbit aortic smooth muscle: role of NF-kappa B. Am J Physiol Heart Circ Physiol. 2002;283:H227-H237.

164 Sardi SP, Rey-Ares V, Pujol-Lereis VA, Serrano SA, Rothlin RP. Further pharmacological evidence of nuclear factor-kappaB pathway involvement in bradykinin $\mathrm{B}(1)$ receptor-sensitized responses in human umbilical vein. J Pharmacol Exp Ther. 2002;301:975-980.

165 Schanstra JP, Bataille E, Marin Castano ME, Barascud Y, Hirtz C, Pesquero JB, et al. The B1-agonist [des-Arg10]-kallidin activates transcription factor NF-kappaB and induces homologous upregulation of the bradykinin B1-receptor in cultured human lung fibroblasts. J Clin Invest. 1998;101:2080-2091.

166 Phagoo SB, Poole S, Leeb-Lundberg LM. Autoregulation of bradykinin receptors: agonists in the presence of interleukin1beta shift the repertoire of receptor subtypes from B2 to B1 in human lung fibroblasts. Mol Pharmacol. 1999;56:325-333.

167 Bastian S, Paquet JL, Robert C, Cremers B, Loillier B, Larrivee $\mathrm{JF}$, et al. Interleukin 8 (IL-8) induces the expression of kinin B1 receptor in human lung fibroblasts. Biochem Biophys Res Commun. 1998;253:750-755. 
168 Sabourin T, Guay K, Houle S, Bouthillier J, Bachvarov PR, Adam A, et al. Absence of ligand-induced regulation of kinin receptor expression in the rabbit. Br J Pharmacol. 2001;133: 1154-1162.

169 Yang X, Taylor L, Yu J, Fenton MJ, Polgar P. Mediator caused induction of a human bradykinin $\mathrm{B} 1$ receptor minigene: participation of c-Jun in the process. J Cell Biochem. 2001;82:163170.

170 Pesquero JB, Lindsey CJ, Paiva AC, Ganten D, Bader M. Transcriptional regulatory elements in the rat bradykinin B2 receptor gene. Immunopharmacology. 1996;33:36-41.

171 Baptista HA, Avellar MC, Araujo RC, Pesquero JL, Schanstra JP, Bascands JL, et al. Transcriptional regulation of the rat bradykinin B2 receptor gene: identification of a silencer element. Mol Pharmacol. 2002;62:1344-1355.

172 Schmidlin F, Scherrer D, Daeffler L, Bertrand C, Landry Y, Gies JP. Interleukin-1beta induces bradykinin B2 receptor gene expression through a prostanoid cyclic AMP-dependent pathway in human bronchial smooth muscle cells. Mol Pharmacol. 1998;53:1009-1015.

173 Yusuf S, Sleight P, Pogue J, Bosch J, Davies R, Dagenais G. Effects of an angiotensin-converting-enzyme inhibitor, ramipril, on cardiovascular events in high-risk patients. The Heart Outcomes Prevention Evaluation Study Investigators. N Engl J Med. 2000;342:145-153.

174 Busse R, Fleming I. Molecular responses of endothelial tissue to kinins. Diabetes. 1996;45 Suppl 1:S8-S13.

175 Velarde V, Ullian ME, Morinelli TA, Mayfield RK, Jaffa AA. Mechanisms of MAPK activation by bradykinin in vascular smooth muscle cells. Am J Physiol. 1999;277:C253-C261.

176 Fleming I, Fisslthaler B, Busse R. Calcium signaling in endothelial cells involves activation of tyrosine kinases and leads to activation of mitogen-activated protein kinases. Circ Res. 1995;76:522-529.

177 Fleming I, Fisslthaler B, Busse R. Interdependence of calcium signaling and protein tyrosine phosphorylation in human endothelial cells. J Biol Chem. 1996;271:11009-11015.

178 Harris MB, Ju H, Venema VJ, Blackstone M, Venema RC. Role of heat shock protein 90 in bradykinin-stimulated endothelial nitric oxide release. Gen Pharmacol. 2000;35:165-170.

179 Marrero MB, Venema VJ, Ju H, He H, Liang H, Caldwell RB, et al. Endothelial nitric oxide synthase interactions with Gprotein-coupled receptors. Biochem J. 1999;343 Pt 2:335-340.

180 Venema RC. Post-translational mechanisms of endothelial nitric oxide synthase regulation by bradykinin. Int Immunopharmacol. 2002;2:1755-1762.

$181 \mathrm{Ju}$ H, Venema VJ, Liang H, Harris MB, Zou R, Venema RC. Bradykinin activates the Janus-activated kinase/signal transducers and activators of transcription (JAK/STAT) pathway in vascular endothelial cells: localization of JAK/STAT signalling proteins in plasmalemmal caveolae. Biochem J. 2000;351:257264.

182 Faussner A, Proud D, Towns M, Bathon JM. Influence of the cytosolic carboxyl termini of human B1 and B2 kinin receptors on receptor sequestration, ligand internalization, and signal transduction. J Biol Chem. 1998;273:2617-2623.

183 de Weerd WF, Leeb-Lundberg LM. Bradykinin sequesters B2 bradykinin receptors and the receptor-coupled Galpha subunits Galphaq and Galphai in caveolae in DDT1 MF-2 smooth muscle cells. J Biol Chem. 1997;272:17858-17866.

184 Blaukat A, Alla SA, Lohse MJ, Muller-Esterl W. Ligand- induced phosphorylation/dephosphorylation of the endogenous bradykinin B2 receptor from human fibroblasts. J Biol Chem. 1996;271:32366-32374.

185 Houle S, Molinaro G, Adam A, Marceau F. Tissue kallikrein actions at the rabbit natural or recombinant kinin $\mathrm{B} 2$ receptors. Hypertension. 2003;41:611-617.

186 Blaukat A, Pizard A, Rajerison RM, Alhenc-Gelas F, MullerEsterl W, Dikic I. Activation of mitogen-activated protein kinase by the bradykinin $\mathrm{B} 2$ receptor is independent of receptor phosphorylation and phosphorylation-triggered internalization. FEBS Lett. 1999;451:337-341.

187 Sabourin T, Bastien L, Bachvarov DR, Marceau F. Agonistinduced translocation of the kinin $\mathrm{B}(1)$ receptor to caveolaerelated rafts. Mol Pharmacol. 2002;61:546-553.

188 Colman RW, Wong PY. Participation of Hageman factor dependent pathways in human disease states. Thromb Haemost. 1977;38:751-775.

189 Braat EA, Dooijewaard G, Rijken DC. Fibrinolytic properties of activated FXII. Eur J Biochem. 1999;263:904-911.

190 Agostoni A, Aygoren-Pursun E, Binkley KE, Blanch A, Bork K, Bouillet L, et al. Hereditary and acquired angioedema: problems and progress: proceedings of the third $\mathrm{C} 1$ esterase inhibitor deficiency workshop and beyond. J Allergy Clin Immunol. 2004;114:S51-S131.

191 Nussberger J, Cugno M, Amstutz C, Cicardi M, Pellacani A, Agostoni A. Plasma bradykinin in angio-oedema. Lancet. 1998; 351:1693-1697.

192 Nussberger J, Cugno M, Cicardi M. Bradykinin-mediated angioedema. N Engl J Med. 2002;347:621-622.

193 Davis AE. The pathogenesis of hereditary angioedema. Transfus Apheresis Sci. 2003;29:195-203.

194 Cugno M, Nussberger J, Cicardi M, Agostoni A. Bradykinin and the pathophysiology of angioedema. Int Immunopharmacol. 2003;3:311-317.

195 Agostoni A, Cicardi M. Hereditary and acquired C1-inhibitor deficiency: biological and clinical characteristics in 235 patients. Medicine (Baltimore). 1992;71:206-215.

196 Zuraw BL. Current and future therapy for hereditary angioedema. Clin Immunol. 2005;114:10-16

197 Han ED, MacFarlane RC, Mulligan AN, Scafidi J, Davis AE $3 \mathrm{rd}$. Increased vascular permeability in $\mathrm{C} 1$ inhibitor-deficient mice mediated by the bradykinin type 2 receptor. J Clin Invest. 2002;109:1057-1063

198 Bork K, Dewald G. Hereditary angioedema type III, angioedema associated with angiotensin II receptor antagonists, and female sex. Am J Med. 2004;116:644-645.

199 Engh RA, Huber R, Bode W, Schulze AJ. Divining the serpin inhibition mechanism: a suicide substrate 'springe'? Trends Biotechnol. 1995;13:503-510.

200 Alston TA. Aprotinin. Int Anesthesiol Clin. 2004;42:81-91.

201 Nagaya M, Futamura M, Kato J, Niimi N, Fukuta S. Application of a new anticoagulant (Nafamostat Mesilate) to control hemorrhagic complications during extracorporeal membrane oxygenation - a preliminary report. J Pediatr Surg. 1997;32:531-535.

202 Nakamura K, Onitsuka T, Yano M, Nagahama H, Nakamura E, Matsuzaki Y. Nafamostat mesilate treatment during open heart operation in immune thrombocytopenic purpura. Ann Thorac Surg. 2000;70:2161-2163.

203 De Serres J, Groner A, Lindner J. Safety and efficacy of pasteurized $\mathrm{C} 1$ inhibitor concentrate $(\operatorname{Berinert}((\mathrm{R})) \mathrm{P})$ in hereditary angioedema: a review. Transfus Apheresis Sci. 2003;29: 
247-254.

204 Han Lee ED, Pappalardo E, Scafidi J, Davis AE. Approaches toward reversal of increased vascular permeability in $\mathrm{C} 1$ inhibitor deficient mice. Immunol Lett. 2003;89:155-160.

205 Cicardi M, Zingale L. How do we treat patients with hereditary angioedema. Transfus Apheresis Sci. 2003;29:221-227.

206 Pappalardo E, Zingale LC, Cicardi M. Increased expression of C1-inhibitor mRNA in patients with hereditary angioedema treated with Danazol. Immunol Lett. 2003;86:271-276.

207 Wellington K, Wagstaff AJ. Tranexamic acid: a review of its use in the management of menorrhagia. Drugs. 2003;63:1417-1433.

208 Dunn CJ, Goa KL. Tranexamic acid: a review of its use in surgery and other indications. Drugs. 1999;57:1005-1032.

209 Rosenkrans B, Russmann S, Reichen J, Brunner-Ferber F, Bork K, Knolle J. Clinical proof-of-concept fort he bradykinin B2 antagonist; icatibant in liver cirrhosis and hereditary angioedema. Peptide Receptors Montreal 2004 Symposium. Montreal, Canada, 2004

210 Mattsson E, Herwald H, Cramer H, Persson K, Sjobring U, Bjorck L. Staphylococcus aureus induces release of bradykinin in human plasma. Infect Immun. 2001;69:3877-3882.

211 Ueno A, Tokumasu T, Naraba H, Oh-ishi S. The mediators involved in endotoxin-induced vascular permeability increase in the rat skin and their interactions. Jpn J Pharmacol. 1996; 70:285-290.

212 Shima C, Majima M, Katori M. A stable metabolite, Arg-ProPro-Gly-Phe, of bradykinin in the degradation pathway in human plasma. Jpn J Pharmacol. 1992;60:111-119.

213 Morinelli TA, Webb JG, Jaffa AA, Privitera PJ, Margolius HS. A metabolic fragment of bradykinin, Arg-Pro-Pro-Gly-Phe, protects against the deleterious effects of lipopolysaccharide in rats. J Pharmacol Exp Ther. 2001;296:71-76.

214 Nieman MT, Warnock M, Hasan AA, Mahai F, Lucchesi BR, Brown NJ, et al. The preparation and characterization of novel peptide antagonists to thrombin and factor VIIa and activation of protease-activated receptor 1. J Pharmacol Exp Ther. 2004;311: 492-501.

215 Verresen L, Waer M, Vanrenterghem Y, Michielsen P. Angiotensin-converting-enzyme inhibitors and anaphylactoid reactions to high-flux membrane dialysis. Lancet. 1990;336:1360-1362.

216 Cyr M, Eastlund T, Blais C Jr, Rouleau JL, Adam A. Bradykinin metabolism and hypotensive transfusion reactions. Transfusion. 2001;41:136-150.

217 Cugno M, Cicardi M, Agostoni A. Activation of the contact system and fibrinolysis in autoimmune acquired angioedema: a rationale for prophylactic use of tranexamic acid. J Allergy Clin Immunol. 1994;93:870-876.

218 Pretorius M, Rosenbaum D, Vaughan DE, Brown NJ. Angiotensin-converting enzyme inhibition increases human vascular tissue-type plasminogen activator release through endogenous bradykinin. Circulation. 2003;107:579-585.

219 Soubrier F, Hubert C, Testut P, Nadaud S, Alhenc-Gelas F, Corvol P. Molecular biology of the angiotensin I converting enzyme: I. Biochemistry and structure of the gene. J Hypertens. 1993;11:471-476.

220 Crackower MA, Sarao R, Oudit GY, Yagil C, Kozieradzki I, Scanga SE, et al. Angiotensin-converting enzyme 2 is an essential regulator of heart function. Nature. 2002;417:822-828.

221 Mancini GB, Henry GC, Macaya C, O’Neill BJ, Pucillo AL, Carere RG, et al. Angiotensin-converting enzyme inhibition with quinapril improves endothelial vasomotor dysfunction in patients with coronary artery disease. The TREND (Trial on Reversing ENdothelial Dysfunction) Study. Circulation. 1996; 94:258-265.

222 Yusuf S, Sleight P, Pogue J, Bosch J, Davies R, Dagenais G. Effects of an angiotensin-converting-enzyme inhibitor, ramipril, on cardiovascular events in high-risk patients. The Heart Outcomes Prevention Evaluation Study Investigators. N Engl J Med. 2000;342:145-153.

223 White HD. Should all patients with coronary disease receive angiotensin-converting-enzyme inhibitors? Lancet. 2003;362:755757.

224 Pfeffer MA, Braunwald E, Moye LA, Basta L, Brown EJ Jr, Cuddy TE, et al. Effect of captopril on mortality and morbidity in patients with left ventricular dysfunction after myocardial infarction. Results of the survival and ventricular enlargement trial. The SAVE Investigators. N Engl J Med. 1992;327:669677.

225 Kober L, Torp-Pedersen C, Carlsen JE, Bagger H, Eliasen P, Lyngborg $\mathrm{K}$, et al. A clinical trial of the angiotensin-convertingenzyme inhibitor trandolapril in patients with left ventricular dysfunction after myocardial infarction. Trandolapril Cardiac Evaluation (TRACE) Study Group. N Engl J Med. 1995;333: 1670-1676.

226 Borghi C, Bacchelli S, Degli Esposti D, Ambrosioni E. A review of the angiotensin-converting enzyme inhibitor, zofenopril, in the treatment of cardiovascular diseases. Expert Opin Pharmacother. 2004;5:1965-1977.

227 Lewis EJ. The treatment of hypertension in diabetic nephropathy. J Hum Hypertens. 1996;10:675-677.

228 Pahor M, Psaty BM, Alderman MH, Applegate WB, Williamson JD, Furberg CD. Therapeutic benefits of ACE inhibitors and other antihypertensive drugs in patients with type 2 diabetes. Diabetes Care. 2000;23:888-892.

229 Boos CJ, Dawes M. ACE cardiovascular protection: EUROPA versus HOPE. Cardiovasc Drugs Ther. 2004;18:179-180.

230 Perez M, Molinaro G, Adam A. Bradykinin, an important mediator of the cardiovascular effects of metallopeptidase inhibitors: experimental and clinical evidences. J Clin Basic Cardiol. 2001;4:39-46.

231 Gainer JV, Morrow JD, Loveland A, King DJ, Brown NJ. Effect of bradykinin-receptor blockade on the response to angiotensinconverting-enzyme inhibitor in normotensive and hypertensive subjects. N Engl J Med. 1998;339:1285-1292.

232 Molinaro G, Rouleau JL, Adam A. Vasopeptidase inhibitors: a new class of dual zinc metallopeptidase inhibitors for cardiorenal therapeutics. Curr Opin Pharmacol. 2002;2:131-141.

233 Trippodo NC, Fox M, Monticello TM, Panchal BC, Asaad MM. Vasopeptidase inhibition with omapatrilat improves cardiac geometry and survival in cardiomyopathic hamsters more than does ACE inhibition with captopril. J Cardiovasc Pharmacol. 1999;34:782-790.

234 McClean DR, Ikram H, Garlick AH, Richards AM, Nicholls MG, Crozier IG. The clinical, cardiac, renal, arterial and neurohormonal effects of omapatrilat, a vasopeptidase inhibitor, in patients with chronic heart failure. J Am Coll Cardiol. 2000; 36:479-486.

235 Rouleau JL, Pfeffer MA, Stewart DJ, Isaac D, Sestier F, Kerut EK, et al. Comparison of vasopeptidase inhibitor, omapatrilat, and lisinopril on exercise tolerance and morbidity in patients with heart failure: IMPRESS randomised trial. Lancet. 2000; 356:615-620. 
236 Kostis JB, Packer M, Black HR, Schmieder R, Henry D, Levy E. Omapatrilat and enalapril in patients with hypertension: the Omapatrilat Cardiovascular Treatment vs. Enalapril (OCTAVE) trial. Am J Hypertens. 2004;17:103-111.

237 Zanchi A, Maillard M, Burnier M. Recent clinical trials with omapatrilat: new developments. Curr Hypertens Rep. 2003;5: 346-352.

238 Packer M, Califf RM, Konstam MA, Krum H, McMurray JJ, Rouleau JL, et al. Comparison of omapatrilat and enalapril in patients with chronic heart failure: the Omapatrilat Versus Enalapril Randomized Trial of Utility in Reducing Events (OVERTURE). Circulation. 2002;106:920-926.

239 Dumoulin MJ, Adam A, Rouleau JL, Lamontagne D. Comparison of a vasopeptidase inhibitor with neutral endopeptidase and angiotensin-converting enzyme inhibitors on bradykinin metabolism in the rat coronary bed. J Cardiovasc Pharmacol. 2001; 37:359-366.

240 Raut R, Rouleau JL, Blais C Jr, Gosselin H, Molinaro G, Sirois $\mathrm{MG}$, et al. Bradykinin metabolism in the postinfarcted rat heart: role of ACE and neutral endopeptidase 24.11. Am J Physiol. 1999;276:H1769-H1779.

241 Dumoulin MJ, Lamontagne D, Burnett J, Heublein D, Yamaguchi N, Adam A. Respective role of endogenous kinins and natriuretic peptides in the cardioprotective effect of omapatrilat following total heart ischemia (abstract). Eur Heart J. 2001;22:50.

242 Bralet J, Schwartz JC. Vasopeptidase inhibitors: an emerging class of cardiovascular drugs. Trends Pharmacol Sci. 2001;22: 106-109.

243 Dumoulin MJ, Adam A, Burnett J, Heublein D, Yamaguchi N, Lamontagne D. The cardioprotective effect of dual metallopeptidase inhibition: respective roles of endogenous kinins and natriuretic peptides. Can J Physiol Pharmacol. 2005;83:166-173.

244 Hill MD, Barber PA, Takahashi J, Demchuk AM, Feasby TE, Buchan AM. Anaphylactoid reactions and angioedema during alteplase treatment of acute ischemic stroke. Cmaj. 2000;162: 1281-1284.

245 Molinaro G, Adam A, Lepage Y, Hammerschmidt D, Koenigbauer $U$, Eastlund $T$. Hypotensive reaction during staphylococcal protein A column therapy in a patient with anomalous degradation of bradykinin and Des-Arg9-bradykinin after contact activation. Transfusion. 2002;42:1458-1465.

246 Coletta A, Thackray S, Nikitin N, Cleland JG. Clinical trials update: highlights of the scientific sessions of The American College of Cardiology 2002: LIFE, DANAMI 2, MADIT-2, MIRACLE-ICD, OVERTURE, OCTAVE, ENABLE 1 \& 2 , CHRISTMAS, AFFIRM, RACE, WIZARD, AZACS, REMATCH, BNP trial and HARDBALL. Eur J Heart Fail. 2002;4:381-388.

247 Adam A, Cugno M, Molinaro G, Perez M, Lepage Y, Agostoni A. Aminopeptidase $\mathrm{P}$ in individuals with a history of angiooedema on ACE inhibitors. Lancet. 2002;359:2088-2089.

248 Molinaro G, Cugno M, Perez M, Lepage Y, Gervais N, Agostoni $\mathrm{A}$, et al. Angiotensin-converting enzyme Inhibitor-associated angioedema is characterized by a slower degradation of desArginine9-Bradykinin. J Pharmacol Exp Ther. 2002;303:232237.

249 Arnold DM, Molinaro G, Warkentin TE, DiTomasso J, Webert KE, Davis I, et al. Hypotensive transfusion reactions can occur with blood products that are leukoreduced before storage. Transfusion. 2004;44:1361-1366.

250 Duan Q, Nikpoor B, Molinaro G, Meijer I, Rochefort D, Saint-
Onge $\mathrm{J}$, et al. Variants in XPNPEP2 increase susceptibility to ACE-inhibitor associated adverse reactions. Am J Hum Genet. In press 2005.

251 Lefebvre J, Murphey LJ, Hartert TV, Jiao Shan R, Simmons WH, Brown NJ. Dipeptidyl peptidase IV activity in patients with ACE-inhibitor-associated angioedema. Hypertension. 2002;39: 460-464.

252 Houle S, Landry M, Audet R, Bouthillier J, Bachvarov DR, Marceau F. Effect of allelic polymorphism of the B(1) and B(2) receptor genes on the contractile responses of the human umbilical vein to kinins. J Pharmacol Exp Ther. 2000;294:4551.

253 Pe'er I, Beckmann JS. On the applicability of a haplotype map to un-assayed populations. Hum Genet. 2004;114:214-217.

254 Hess JF, Hey PJ, Chen TB, Pettibone DJ, Chang RS. Molecular and pharmacological diversity of the kinin B1 receptor. Int Immunopharmacol. 2002;2:1747-1754.

255 Brull D, Dhamrait S, Myerson S, Erdmann J, Woods D, World $\mathrm{M}$, et al. Bradykinin B2BKR receptor polymorphism and leftventricular growth response. Lancet. 2001;358:1155-1156.

256 Hallberg P, Lind L, Michaelsson K, Karlsson J, Kurland L, Kahan T, et al. B2 bradykinin receptor (B2BKR) polymorphism and change in left ventricular mass in response to antihypertensive treatment: results from the Swedish Irbesartan Left Ventricular Hypertrophy Investigation versus Atenolol (SILVHIA) trial. J Hypertens. 2003;21:621-624.

257 Williams AG, Dhamrait SS, Wootton PT, Day SH, Hawe E, Payne JR, et al. Bradykinin receptor gene variant and human physical performance. J Appl Physiol. 2004;96:938-942.

258 Dhamrait SS, Payne JR, Li P, Jones A, Toor IS, Cooper JA, et al. Variation in bradykinin receptor genes increases the cardiovascular risk associated with hypertension. Eur Heart J. 2003; 24:1672-1680

259 Maltais I, Bachvarova M, Maheux P, Perron P, Marceau F, Bachvarov D. Bradykinin B2 receptor gene polymorphism is associated with altered urinary albumin/creatinine values in diabetic patients. Can J Physiol Pharmacol. 2002;80:323-327.

260 Zee RY, Rao VS, Paster RZ, Sweet CS, Lindpaintner K. Three candidate genes and angiotensin-converting enzyme inhibitorrelated cough: a pharmacogenetic analysis. Hypertension. 1998; 31:925-928.

261 Cui J, Melista E, Chazaro I, Zhang Y, Zhou X, Manolis AJ, et al. Sequence variation of bradykinin receptors $\mathrm{B} 1$ and $\mathrm{B} 2$ and association with hypertension. J Hypertens. 2005;23:55-62.

262 Gainer JV, Brown NJ, Bachvarova M, Bastien L, Maltais I, Marceau F, et al. Altered frequency of a promoter polymorphism of the kinin B2 receptor gene in hypertensive AfricanAmericans. Am J Hypertens. 2000;13:1268-1273.

263 Wang B, Dang A, Liu G. Genetic variation in the promoter region of the beta 2 bradykinin receptor gene is associated with essential hypertension in a Chinese Han population. Hypertens Res. 2001;24:299-302.

264 Mukae S, Aoki S, Itoh S, Iwata T, Ueda H, Katagiri T. Bradykinin $\mathrm{B}(2)$ receptor gene polymorphism is associated with angiotensin-converting enzyme inhibitor-related cough. Hypertension. 2000;36:127-131.

265 Zychma MJ, Gumprecht J, Trautsolt W, Szydlowska I, Grzeszczak W. Polymorphic genes for kinin receptors, nephropathy and blood pressure in type 2 diabetic patients. Am J Nephrol. 2003;23:112-116.

266 Bachvarov DR, Landry M, Pelletier I, Chevrette M, Betard C, 
Houde I, et al. Characterization of two polymorphic sites in the human kinin B1 receptor gene: altered frequency of an allele in patients with a history of end-stage renal failure. J Am Soc Nephrol. 1998;9:598-604.

267 Bachvarov DR, Landry M, Houle S, Pare P, Marceau F. Altered frequency of a promoter polymorphic allele of the kinin B1 receptor gene in inflammatory bowel disease. Gastroenterology. 1998;115:1045-1048.

268 Ueno A, Oh-ishi S. Roles for the kallikrein-kinin system in inflammatory exudation and pain: lessons from studies on kininogen-deficient rats. J Pharmacol Sci. 2003;93:1-20.

269 Akbary AM, Wirth KJ, Scholkens BA. Efficacy and tolerability of Icatibant (Hoe 140) in patients with moderately severe chronic bronchial asthma. Immunopharmacology. 1996;33:238242.

270 Turner P, Dear J, Scadding G, Foreman JC. Role of kinins in seasonal allergic rhinitis: icatibant, a bradykinin B2 receptor antagonist, abolishes the hyperresponsiveness and nasal eosinophilia induced by antigen. J Allergy Clin Immunol. 2001;107: 105-113.

271 Proud D, Bathon JM, Togias AG, Naclerio RM. Inhibition of the response to nasal provocation with bradykinin by HOE-140: efficacy and duration of action. Can J Physiol Pharmacol. 1995;73:820-826.

272 Fein AM, Bernard GR, Criner GJ, Fletcher EC, Good JT Jr, Knaus WA, et al. Treatment of severe systemic inflammatory response syndrome and sepsis with a novel bradykinin antagonist, deltibant (CP-0127). Results of a randomized, double-blind, placebo-controlled trial. CP-0127 SIRS and Sepsis Study Group. Jama. 1997;277:482-487.

273 Heitsch H. The therapeutic potential of bradykinin B2 receptor agonists in the treatment of cardiovascular disease. Expert Opin Investig Drugs. 2003;12:759-770.

274 Groves P, Kurz S, Just H, Drexler H. Role of endogenous bradykinin in human coronary vasomotor control. Circulation. 1995; 92:3424-3430.

275 Regoli DC, Marceau F, Lavigne J. Induction of beta 1-receptors for kinins in the rabbit by a bacterial lipopolysaccharide. Eur $\mathrm{J}$ Pharmacol. 1981;71:105-115.

276 deBlois D, Horlick RA. Endotoxin sensitization to kinin B(1) receptor agonist in a non-human primate model: haemodynamic and pro-inflammatory effects. Br J Pharmacol. 2001;132:327335.

277 Ignarro LJ, Byrns RE, Buga GM, Wood KS. Mechanisms of endothelium-dependent vascular smooth muscle relaxation elicited by bradykinin and VIP. Am J Physiol. 1987;253:H1074-H1082.

278 Zhu P, Zaugg CE, Hornstein PS, Allegrini PR, Buser PT. Bradykinin-dependent cardioprotective effects of losartan against ischemia and reperfusion in rat hearts. J Cardiovasc Pharmacol. 1999;33:785-790.

279 Witherow FN, Helmy A, Webb DJ, Fox KA, Newby DE. Bradykinin contributes to the vasodilator effects of chronic angiotensin-converting enzyme inhibition in patients with heart failure. Circulation. 2001;104:2177-2181.

280 Lagneux C, Adam A, Lamontagne D. A study of the mediators involved in the protection induced by exogenous kinins in the isolated rat heart. Int Immunopharmacol. 2003;3:1511-1518.

281 Emanueli C, Bonaria Salis M, Stacca T, Pintus G, Kirchmair R, Isner JM, et al. Targeting kinin $\mathrm{B}(1)$ receptor for therapeutic neovascularization. Circulation. 2002;105:360-366.

282 Aramori I, Zenkoh J, Morikawa N, O’Donnell N, Asano M,
Nakamura K, et al. Novel subtype-selective nonpeptide bradykinin receptor antagonists FR167344 and FR173657. Mol Pharmacol. 1997;51:171-176.

283 Majima M, Hayashi I, Inamura N, Fujita T, Ogino M. A nonpeptide mimic of bradykinin blunts the development of hypertension in young spontaneously hypertensive rats. Hypertension. 2000;35:437-442.

284 Emerich DF, Dean RL, Osborn C, Bartus RT. The development of the bradykinin agonist labradimil as a means to increase the permeability of the blood-brain barrier: from concept to clinical evaluation. Clin Pharmacokinet. 2001;40:105-123.

285 Liesmaa I, Kuoppala A, Shiota N, Kokkonen JO, Kostner K, Mayranpaa $\mathrm{M}$, et al. Increased expression of bradykinin type-1 receptors in endothelium of intramyocardial coronary vessels in human failing hearts. Am J Physiol Heart Circ Physiol. 2005;288:H2317-H2322.

286 Decarie A, Adam A, Couture R. Effects of captopril and Icatibant on bradykinin (BK) and des [Arg9] BK in carrageenaninduced edema. Peptides. 1996;17:1009-1015.

287 Cruwys SC, Garrett NE, Perkins MN, Blake DR, Kidd BL. The role of bradykinin $\mathrm{B} 1$ receptors in the maintenance of intraarticular plasma extravasation in chronic antigen-induced arthritis. Br J Pharmacol. 1994;113:940-944.

288 Pesquero JB, Araujo RC, Heppenstall PA, Stucky CL, Silva JA $\mathrm{Jr}$, Walther $\mathrm{T}$, et al. Hypoalgesia and altered inflammatory responses in mice lacking kinin B1 receptors. Proc Natl Acad Sci U S A. 2000;97:8140-8145.

289 Dray A, Patel IA, Perkins MN, Rueff A. Bradykinin-induced activation of nociceptors: receptor and mechanistic studies on the neonatal rat spinal cord-tail preparation in vitro. $\mathrm{Br} \mathrm{J}$ Pharmacol. 1992;107:1129-1134.

290 Dray A. Kinins and their receptors in hyperalgesia. Can J Physiol Pharmacol. 1997;75:704-712.

291 Belichard P, Landry M, Faye P, Bachrarov DR, Bouthillier J, Druneau $\mathrm{D}$, et al. Inflammatory hyperalgesia induced by zymosan in the plantar tissue of the rat: effect of kinin receptor antagonists. Immunopharmacology. 2000;46:139-147.

292 Burgess GM, Perkins MN, Rang HP, Campbell EA, Brown MC, McIntyre $\mathrm{P}$, et al. Bradyzide, a potent non-peptide $\mathrm{B}(2)$ bradykinin receptor antagonist with long-lasting oral activity in animal models of inflammatory hyperalgesia. Br J Pharmacol. 2000; 129:77-86.

293 Ma QP, Heavens R. Basal expression of bradykinin B1 receptor in the spinal cord in humans and rats. Neuroreport. 2001;12: 2311-2314.

294 Wotherspoon G, Winter J. Bradykinin B1 receptor is constitutively expressed in the rat sensory nervous system. Neurosci Lett. 2000;294:175-178.

295 Shughrue PJ, Ky B, Austin CP. Localization of B1 bradykinin receptor mRNA in the primate brain and spinal cord: an in situ hybridization study. J Comp Neurol. 2003;465:372-384.

296 Ongali B, Campos MM, Petcu M, Rodi D, Cloutier F, Chabot $\mathrm{JG}$, et al. Expression of kinin B1 receptors in the spinal cord of streptozotocin-diabetic rat. Neuroreport. 2004;15:2463-2466.

297 Zausinger S, Lumenta DB, Pruneau D, Schmid-Elsaesser R, Plesnila N, Baethmann A. Therapeutical efficacy of a novel non-peptide bradykinin $\mathrm{B} 2$ receptor antagonist on brain edema formation and ischemic tissue damage in focal cerebral ischemia. Acta Neurochir Suppl. 2003;86:205-207.

298 Zausinger S. Bradykinin receptor antagonists in cerebral ischemia and trauma. IDrugs. 2003;6:970-975. 
299 Prat A, Biernacki K, Pouly S, Nalbantoglu J, Couture R, Antel JP. Kinin B1 receptor expression and function on human brain endothelial cells. J Neuropathol Exp Neurol. 2000;59:896-906.

300 Prat A, Weinrib L, Becher B, Poirier J, Duquette P, Couture R, et al. Bradykinin $\mathrm{B} 1$ receptor expression and function on $\mathrm{T}$ lymphocytes in active multiple sclerosis. Neurology. 1999;53: 2087-2092.

301 Bregola G, Varani K, Gessi S, Beani L, Bianchi C, Borea PA, et al. Changes in hippocampal and cortical B1 bradykinin receptor biological activity in two experimental models of epilepsy. Neuroscience. 1999;92:1043-1049.

302 Jaggar SI, Habib S, Rice AS. The modulatory effects of bradykinin B1 and B2 receptor antagonists upon viscero-visceral hyper-reflexia in a rat model of visceral hyperalgesia. Pain. 1998;75:169-176.

303 Stadnicki A, Pastucha E, Nowaczyk G, Mazurek U, Plewka D, Machinik G, et al. Immunolocalization and expression of kinin $\mathrm{B} 1 \mathrm{R}$ and $\mathrm{B} 2 \mathrm{R}$ receptors in human inflammatory bowel disease. Am J Physiol Gastrointest Liver Physiol. 2005;289:G361-G366.

304 Gabra BH, Sirois P. Kinin B1 receptor antagonists inhibit diabetes-induced hyperalgesia in mice. Neuropeptides. 2003;37: 36-44.

305 Gabra BH, Sirois P. Beneficial effect of chronic treatment with the selective bradykinin $\mathrm{B} 1$ receptor antagonists, R-715 and R954, in attenuating streptozotocin-diabetic thermal hyperalgesia in mice. Peptides. 2003;24:1131-1139.

306 Zuccollo A, Navarro M, Frontera M, Cueva F, Carattino M, Catanzaro OL. The involvement of kallikrein-kinin system in diabetes type I (insulitis). Immunopharmacology. 1999;45:69-74.

307 Cloutier F, Couture R. Pharmacological characterization of the cardiovascular responses elicited by kinin $\mathrm{B}(1)$ and $\mathrm{B}(2)$ receptor agonists in the spinal cord of streptozotocin-diabetic rats. Br J Pharmacol. 2000;130:375-385.

308 Campos MM, Cabrini DA, Cardozo AH, Rae GA, Toro JH, Calixto JB. Changes in paw oedema triggered via bradykinin $\mathrm{B}(1)$ and $\mathrm{B}(2)$ receptors in streptozotocin-diabetic rats. Eur $\mathrm{J}$ Pharmacol. 2001;416:169-177.

309 Gabra BH, Sirois P. Role of bradykinin B(1) receptors in diabetes-induced hyperalgesia in streptozotocin-treated mice. Eur J Pharmacol. 2002;457:115-124.

310 Wang CH, Leung N, Lapointe N, Szeto L, Uffelman KD, Giacca A, et al. Vasopeptidase inhibitor omapatrilat induces profound insulin sensitization and increases myocardial glucose uptake in Zucker fatty rats: studies comparing a vasopeptidase inhibitor, angiotensin-converting enzyme Inhibitor, and angiotensin II type I receptor blocker. Circulation. 2003;107:1923-1929.

311 Shiuchi T, Nakagami H, Iwai M, Takeda Y, Cui T, Chen R, et al. Involvement of bradykinin and nitric oxide in leptin-mediated glucose uptake in skeletal muscle. Endocrinology. 2001;142: 608-612.

312 Alfie ME, Sigmon DH, Pomposiello SI, Carretero OA. Effect of high salt intake in mutant mice lacking bradykinin-B2 receptors. Hypertension. 1997;29:483-487.

313 Margolius HS. Theodore Cooper Memorial Lecture. Kallikreins and kinins. Some unanswered questions about system characteristics and roles in human disease. Hypertension. 1995;26:221-
229.

314 Couture R, Girolami JP. Putative roles of kinin receptors in the therapeutic effects of angiotensin 1-converting enzyme inhibitors in diabetes mellitus. Eur J Pharmacol. 2004;500:467-485.

315 Regoli D, Barabe J. Pharmacology of bradykinin and related kinins. Pharmacol Rev. 1980;32:1-46.

316 Berkin KE. Respiratory effects of angiotensin converting enzyme inhibition. Eur Respir J. 1989;2:198-201.

317 Levy D, Zochodne DW. Increased mRNA expression of the B1 and B2 bradykinin receptors and antinociceptive effects of their antagonists in an animal model of neuropathic pain. Pain. 2000;86:265-271.

318 Drapeau G, Audet R, Levesque L, Godin D, Marceau F. Development and in vivo evaluation of metabolically resistant antagonists of B1 receptors for kinins. J Pharmacol Exp Ther. 1993;266:192-199.

319 Eric J, Gabra BH, Sirois P. Implication of the bradykinin receptors in antigen-induced pulmonary inflammation in mice. Br J Pharmacol. 2003;138:1589-1597.

320 Gera L, Stewart JM, Whalley ET, Burkard M, Zuzack JS. New bradykinin antagonists having very high potency at B1 receptors. Immunopharmacology. 1996;33:183-185.

321 Rhaleb NE, Gobeil F, Regoli D. Non-selectivity of new bradykinin antagonists for B1 receptors. Life Sci. 1992;51:PL125PL129.

322 Burkard M, Zuzack JS, Jones S, Francis M, Whalley ET, Stewart $\mathrm{JM}$, et al. Comparative profile of novel potent bradykinin antagonists at human B1 and B2 receptors. Immunopharmacology. 1996;33:186-190.

323 Gama Landgraf R, Jancar S, Steil AA, Sirois P. Modulation of allergic and immune complex-induced lung inflammation by bradykinin receptor antagonists. Inflamm Res. 2004;53:78-83.

324 Christiansen SC, Eddleston J, Woessner KM, Chambers SS, Ye $\mathrm{R}$, Pan ZK, et al. Up-regulation of functional kinin B1 receptors in allergic airway inflammation. J Immunol. 2002;169:20542060.

325 Austin CE, Foreman JC. A study of the action of bradykinin and bradykinin analogues in the human nasal airway. J Physiol (Lond). 1994;478:351-356.

326 Asano M, Hatori C, Inamura N, Sawai H, Hirosumi J, Fujiwara $\mathrm{T}$, et al. Effects of a nonpeptide bradykinin $\mathrm{B} 2$ receptor antagonist, FR167344, on different in vivo animal models of inflammation. Br J Pharmacol. 1997;122:1436-1440.

327 Abe Y, Kayakiri H, Satoh S, Inoue T, Sawada Y, Inamura N, et al. A novel class of orally active non-peptide bradykinin B2 receptor antagonists. 2. Overcoming the species difference between guinea pig and man. J Med Chem. 1998;41:4053-4061.

328 Youngman MA, Carson JR, Lee JS, Dax SL, Zhang SP, Colburn RW, et al. Synthesis and structure - activity relationships of aroylpyrrole alkylamide bradykinin (B2) antagonists. Bioorg Med Chem Lett. 2003;13:1341-1344.

329 Lam YKT, Hensens OD, Ransom R, Giacobbe RA, Polishook J, Zink D. L-755,807, A New Non-Peptide Bradykinin Binding Inhibitor From An Endophytic Microsphaeropsis Sp. Tetrahedron. 1996;52:1481-1486. 